11

Prepared in cooperation with the U.S. Department of the Army Environmental and Natural Resources Management Office of the U.S. Army Signal Center and Fort Gordon

Assessment of Soil-Gas and Soil Contamination at the Former Military Police Range, Fort Gordon, Georgia, 2009-2010
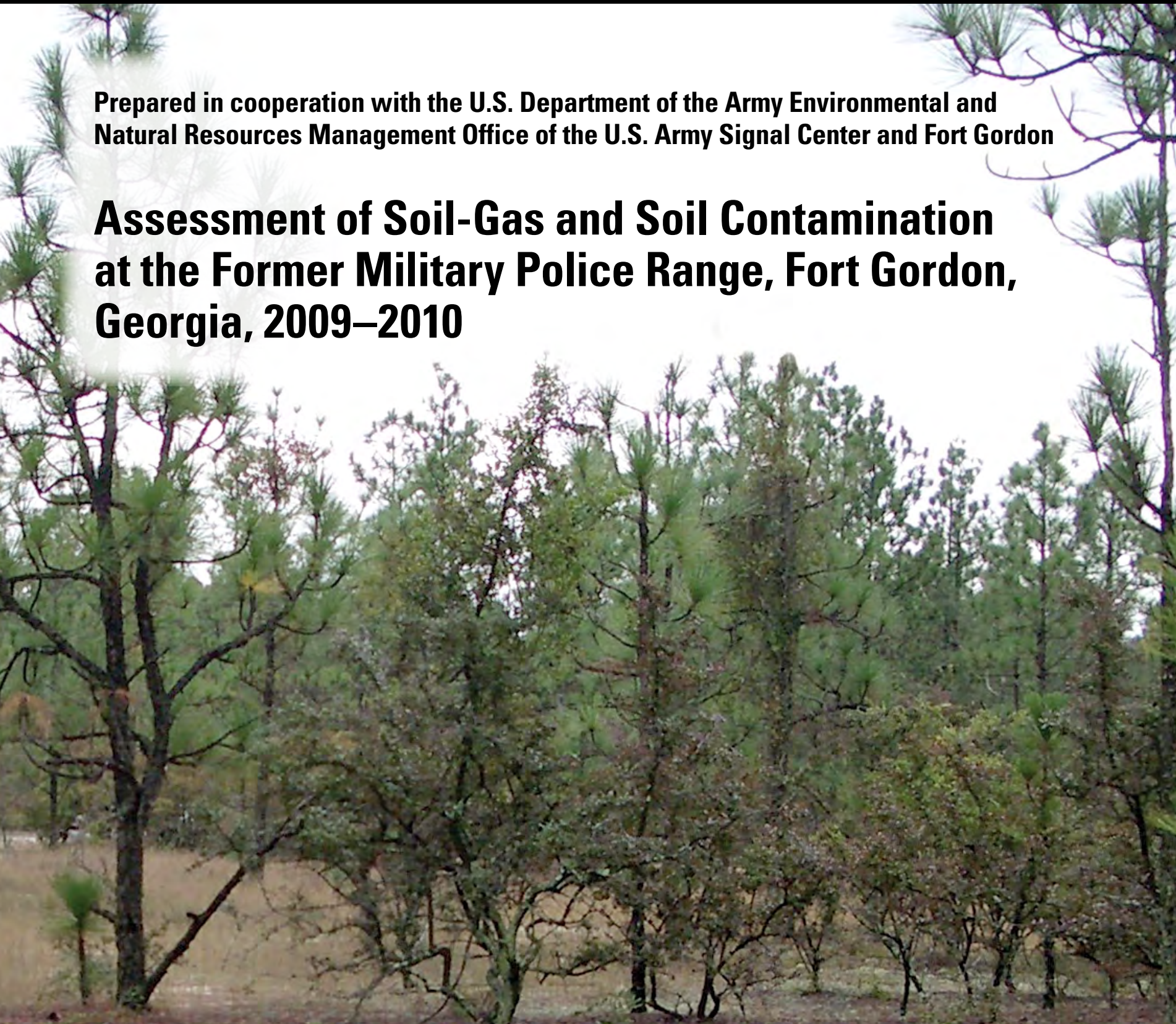

(e.

Open-File Report 2011-1095

U.S. Department of the Interior

U.S. Geological Survey 
Cover photograph. Sparsely wooded sand flat in northern part of former military police range study area (by James E. Landmeyer, USGS). 


\section{Assessment of Soil-Gas and Soil Contamination at the Former Military Police Range, Fort Gordon, Georgia, 2009-2010}

By W. Fred Falls, Andral W. Caldwell, Wladmir B. Guimaraes, W. Hagan Ratliff, John B. Wellborn, and James E. Landmeyer

Prepared in cooperation with the U.S. Department of the Army Environmental and

Natural Resources Management Office of the U.S. Army Signal Center and Fort Gordon

Open-File Report 2011-1095 


\section{U.S. Department of the Interior \\ KEN SALAZAR, Secretary \\ U.S. Geological Survey \\ Marcia K. McNutt, Director}

\section{U.S. Geological Survey, Reston, Virginia: 2011}

For more information on the USGS - the Federal source for science about the Earth, its natural and living resources, natural hazards, and the environment, visit http://www.usgs.gov or call 1-888-ASK-USGS

For an overview of USGS information products, including maps, imagery, and publications, visit $h$ ttp://www.usgs.gov/pubprod

To order this and other USGS information products, visit http://store.usgs.gov

Any use of trade, product, or firm names is for descriptive purposes only and does not imply endorsement by the U.S. Government.

Although this report is in the public domain, permission must be secured from the individual copyright owners to reproduce any copyrighted materials contained within this report.

Suggested citation:

Falls, W.F., Caldwell, A.W., Guimaraes, W.B., Ratliff, W.H., Wellborn, J.B., and Landmeyer, J.E., 2011, Assessment of soil-gas and soil contamination at the former military police range, Fort Gordon, Georgia, 2009-2010: U.S. Geological Survey Open-File Report 2011-1095, 24 p. 


\section{Contents}

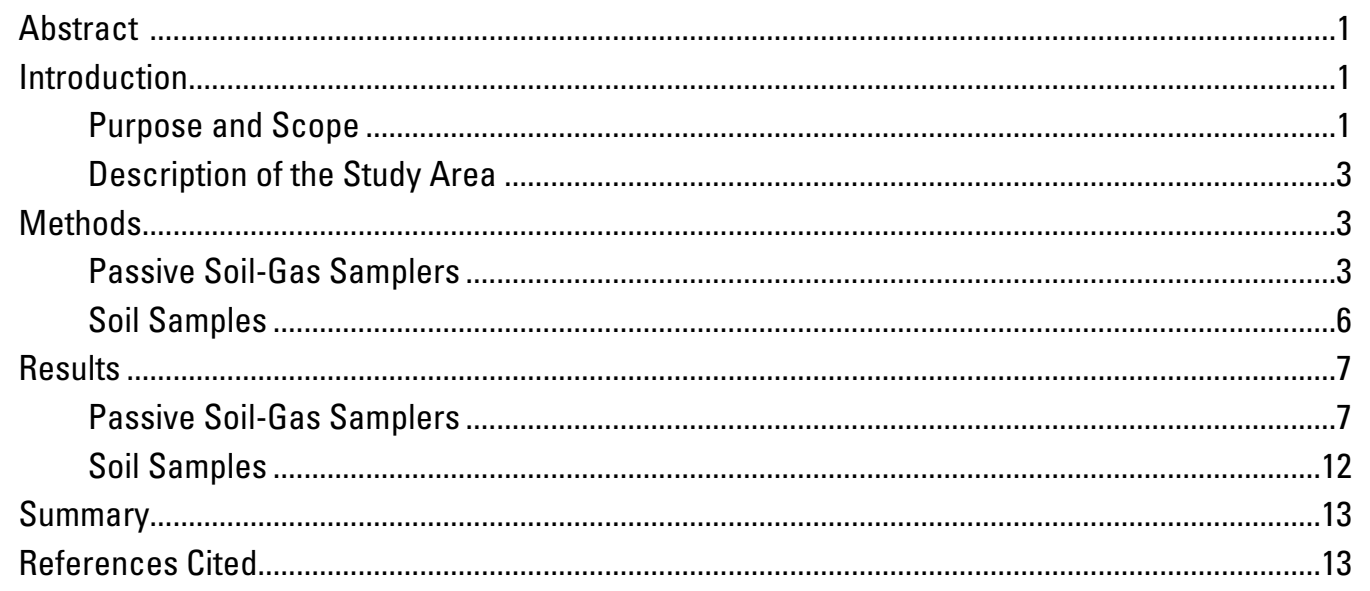




\section{Figures}

1-2. Maps showing-

1. Locations of Fort Gordon and the former military police range study area in Richmond County, Georgia, 2009-2010

2. Locations of the former military police range study area and sampling sites at Fort Gordon in Richmond County, Georgia, 2009-2010 ... 4

3-5. Photographs showing -

3. Soil-gas sampler prior to being installed, and in air-tight vial for shipment from and to the laboratory for analysis.

4. Installation of a passive soil-gas sampler includes drilling a borehole in the soil with a stainless steel drill bit attached to a cordless drill, attaching one end of a string to a sampler and the other end to a cork plug, inserting the sampler on the string into the borehole, and sealing the borehole with the cork plug to keep out surface contaminants.

5. A soil sample collected with a stainless steel hand auger in the interval from land surface to a depth of 6 inches and transferred to a plastic container for shipment to the laboratory.

6-10. Maps showing -

6. Total petroleum hydrocarbon (TPH) mass in soil-gas samplers, former military police range, Fort Gordon, Georgia, May 20-24, 2010

7. Combined benzene, toluene, ethylbenzene, and xylene (gasoline) masses as BTEX in soil-gas samplers, former military police range, Fort Gordon, Georgia, May 20-24, 2010.

8. Combined undecane, tridecane, and pentadecane (diesel) masses in soil-gas samplers, former military police range, Fort Gordon, Georgia, May 20-24, 2010

9. Chloroform and tetrachloroethene masses in soil-gas samplers, former military police range, Fort Gordon, Georgia, May 20-24, 2010.

10. Locations of soil-gas samplers analyzed for organic compounds classified as explosives and chemical agents, September 15-22, 2010, and soil samples analyzed for inorganic constituents, August 30, 2010, former military police range, Fort Gordon, Georgia, 2009-2010.

\section{Tables}

1. Mass of volatile and semivolatile organic compounds detected in soil-gas samplers deployed and collected from the former military police range, Fort Gordon, Georgia, May 20-24, 2010.

2. Mass of volatile and semivolatile organic compounds classified as chemical agents and explosives detected in soil-gas samplers deployed and collected from the former military police range, Fort Gordon, Georgia, September 15-22, 2010

3. Inorganic constituents detected in soil samples collected at the former military police range from land surface to 6 inches, samples 1 through 5, Fort Gordon, Georgia, August 30, 2010 


\section{Conversion Factors}

[Inch/Pound to SI]

\begin{tabular}{|c|c|c|}
\hline Multiply & By & To obtain \\
\hline \multicolumn{3}{|c|}{ Length } \\
\hline inch & 2.54 & centimeter $(\mathrm{cm})$ \\
\hline inch & 25.4 & millimeter $(\mathrm{mm})$ \\
\hline foot $(\mathrm{ft})$ & 0.3048 & meter $(\mathrm{m})$ \\
\hline mile (mi) & 1.609 & kilometer $(\mathrm{km})$ \\
\hline \multicolumn{3}{|c|}{ Area } \\
\hline acre & 4,047 & square meter $\left(\mathrm{m}^{2}\right)$ \\
\hline acre & 0.4047 & hectare (ha) \\
\hline acre & 0.4047 & square hectometer $\left(\mathrm{hm}^{2}\right)$ \\
\hline acre & 0.004047 & square kilometer $\left(\mathrm{km}^{2}\right)$ \\
\hline
\end{tabular}

Horizontal coordinate information is referenced to the North American Datum of 1983 (NAD 83).

Concentrations of chemical constituents in water are given either in milligrams per liter (mg/L) or micrograms per liter $(\mu \mathrm{g} / \mathrm{L})$.

Soil-gas and soil units are given either in micrograms $(\mu \mathrm{g})$, microgram per gram $(\mu \mathrm{g} / \mathrm{g})$, milligram per kilogram $(\mathrm{mg} / \mathrm{kg})$, or milliliter $(\mathrm{mL})$.

\section{Acronyms}

$\begin{array}{ll}\text { bdl } & \text { below detection level } \\ \text { BTEX } & \text { benzene, toluene, ethylbenzene, and xylene (total) } \\ \text { C }_{11^{\prime}} \text { 1 }_{13^{\prime}} \text { and } C_{15} & \text { undecane, tridecane, and pentadecane (total) } \\ \text { FMPR } & \text { former military police range } \\ \text { ICP-MS } & \text { Inductively Coupled Plasma-Mass Spectrometry } \\ \text { MDL } & \text { method detection level } \\ \text { MTBE } & \text { methyl tert-butyl ether } \\ \text { PAH } & \text { polycyclic aromatic hydrocarbon } \\ \text { PCE } & \text { perchloroethene (also known as perchloroethylene and tetrachloroethene) } \\ \text { RCRA } & \text { Resource Conservation and Recovery Act } \\ \text { RSL } & \text { regional screening level } \\ \text { SCDHEC } & \text { South Carolina Department of Health and Environmental Control } \\ \text { SVOC } & \text { semivolatile organic compound } \\ \text { TCE } & \text { trichloroethene (also known as trichloroethylene) } \\ \text { TPH } & \text { total petroleum hydrocarbons } \\ \text { USEPA } & \text { U.S. Environmental Protection Agency } \\ \text { USGS } & \text { U.S. Geological Survey } \\ \text { VOC } & \text { volatile organic compound }\end{array}$





\title{
Assessment of Soil-Gas and Soil Contamination at the Former Military Police Range, Fort Gordon, Georgia, 2009-2010
}

\author{
By W. Fred Falls, ${ }^{1}$ Andral W. Caldwell, ${ }^{1}$ Wladmir B. Guimaraes, ${ }^{1}$ W. Hagan Ratliff, \\ John B. Wellborn, ${ }^{3}$ and James E. Landmeyer'
}

\section{Abstract}

Soil gas and soil were assessed for organic and inorganic contaminants at the former military police range at Fort Gordon, Georgia, from May to September 2010. The assessment evaluated organic contaminants in soil-gas samplers and inorganic contaminants in soil samples. This assessment was conducted to provide environmental contamination data to Fort Gordon pursuant to requirements of the Resource Conservation and Recovery Act Part B Hazardous Waste Permit process.

Soil-gas samplers deployed and collected from May 20 to 24,2010 , identified masses above method detection level for total petroleum hydrocarbons, gasoline-related and dieselrelated compounds, and chloroform. Most of these detections were in the southwestern quarter of the study area and adjacent to the road on the eastern boundary of the site. Nine of the 11 chloroform detections were in the southern half of the study area. One soil-gas sampler deployed adjacent to the road on the southern boundary of the site detected a mass of tetrachloroethene greater than, but close to, the method detection level of 0.02 microgram. For soil-gas samplers deployed and collected from September 15 to 22, 2010, none of the selected organic compounds classified as chemical agents and explosives were detected above method detection levels. Inorganic concentrations in the five soil samples collected at the site did not exceed the U.S. Environmental Protection Agency regional screening levels for industrial soil and were at or below background levels for similar rocks and strata in South Carolina.

\footnotetext{
${ }^{1}$ U.S. Geological Survey, Columbia, South Carolina.

${ }^{2}$ Environmental Branch, Fort Gordon, Georgia.
}

${ }^{3}$ Environmental and Natural Resources Division, Fort Gordon, Georgia.

\section{Introduction}

Fort Gordon is a U.S. Department of the Army facility located in east-central Georgia, approximately 10 miles southwest of Augusta, Georgia (fig. 1). A cantonment (military housing) area is located at the northeastern part of Fort Gordon. Part of the cantonment area consists of an abandoned small-arms firing range that was used to train military police from the 1940 s through the 1960 s. This site is called the former military police range (FMPR) and covers approximately 3 acres. Since the 1960s, the FMPR partially has reverted to woodlands and underbrush.

The effects of past activities at the FMPR on environmental resources currently are unknown. This assessment was conducted to provide screening-level environmental contamination data to Fort Gordon personnel to comply with the requirements of the Resource Conservation and Recovery Act (RCRA) Part B Hazardous Waste Permit process. An initial investigation to assess potential environmental effects is warranted because the FMPR is located in the outcrop area of the Dublin and Midville aquifer systems, which are used for drinking water by the towns of Augusta and Hephzibah (Williams, 2007).

\section{Purpose and Scope}

The U.S. Geological Survey, in cooperation with the U.S. Department of the Army Environmental and Natural Resources Management Office of the U.S. Army Signal Center and Fort Gordon, Georgia, assessed soil gas and soil for contaminants at the FMPR at Fort Gordon, Georgia, from May to September 2010. This initial assessment was conducted to provide environmental contamination data and consists of two passive soil-gas surveys and the collection of soil samples at the FMPR. The report provides the results of analyses for these samples as well as maps showing the location of the more common and noteworthy detections identified in the study area. 


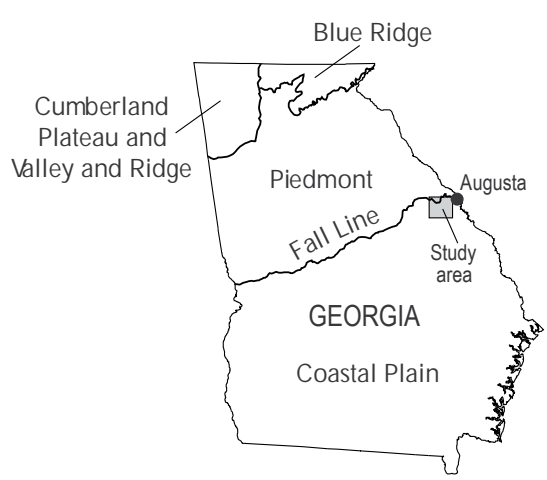

\section{EXPLANATION}

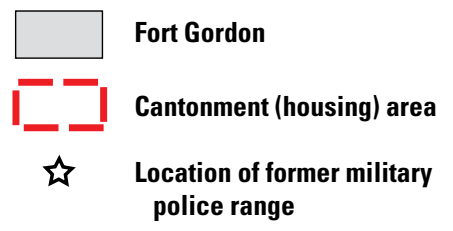

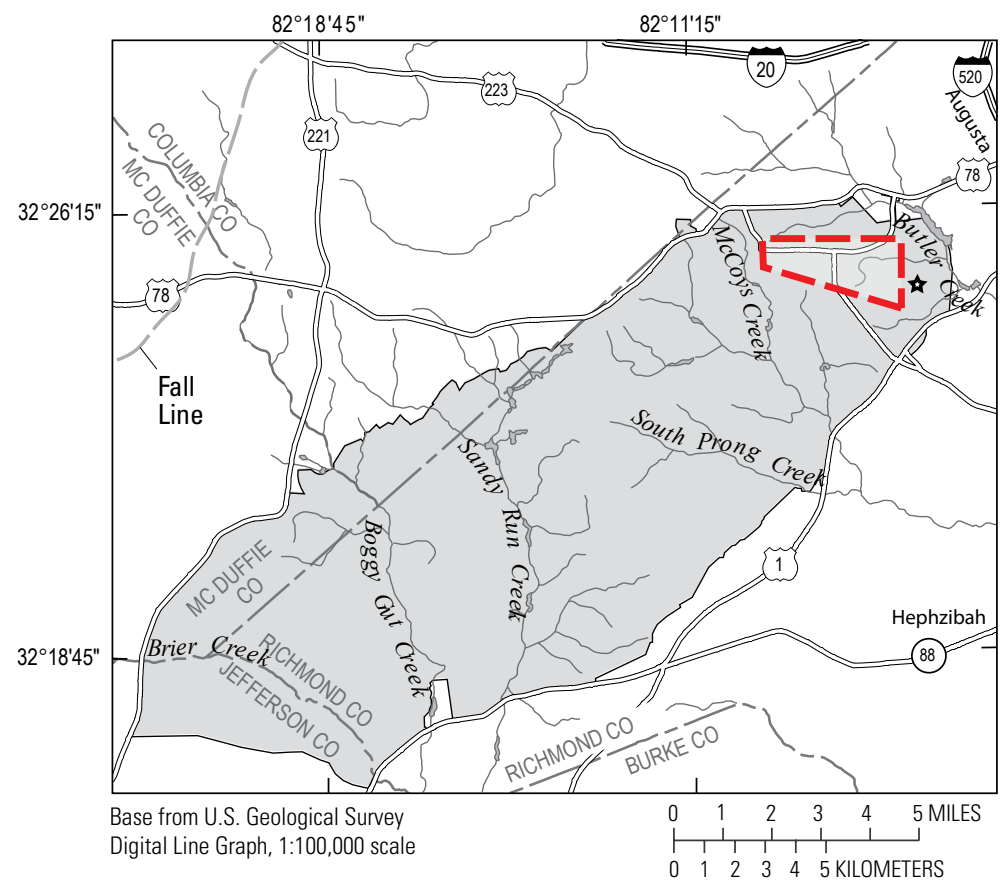

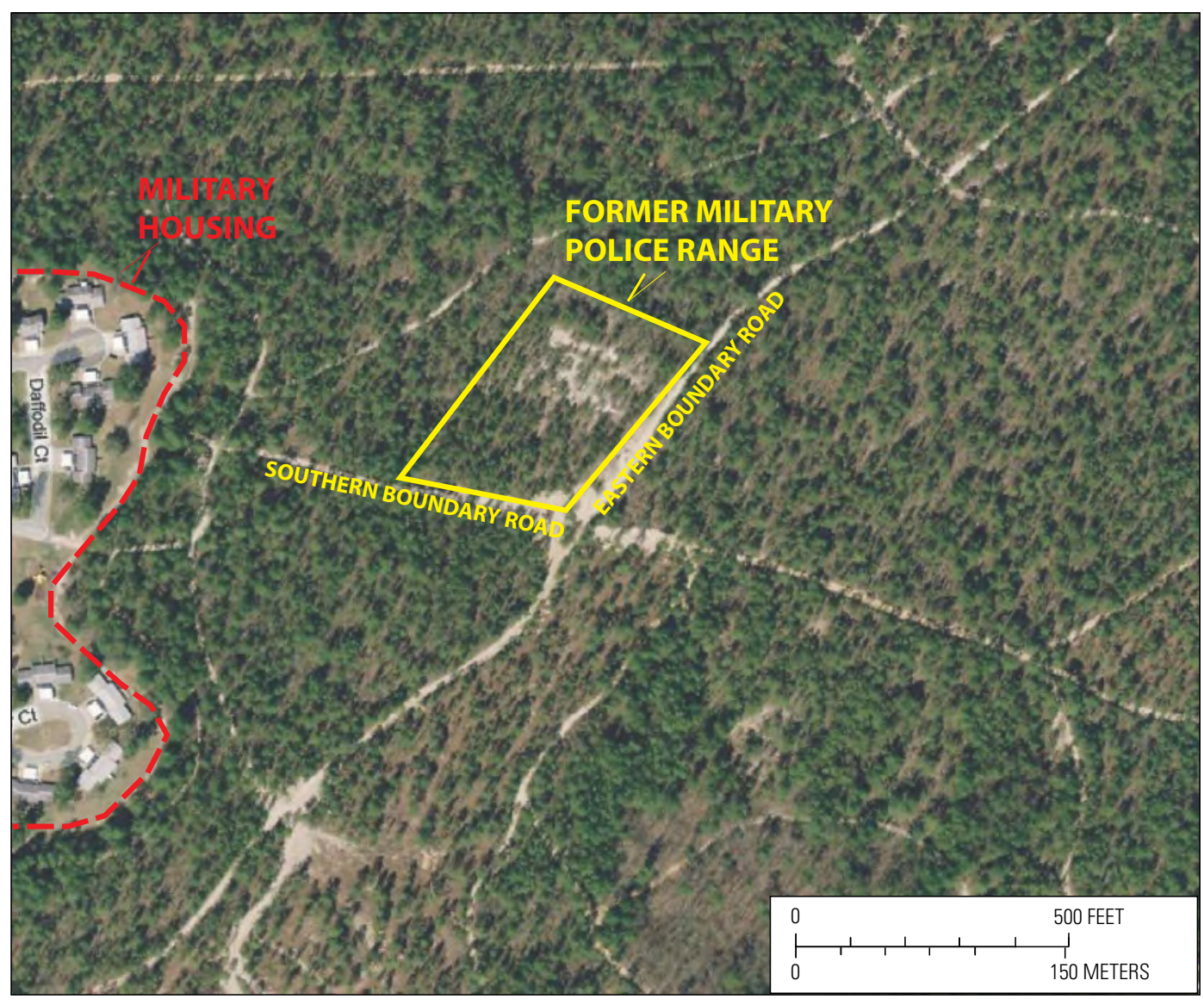

Photograph provided by Hagan Ratliff

Environmental Branch, Fort Gordon, Georgia

Written communication, December 15, 2010

Figure 1. Locations of Fort Gordon and the former military police range study area in Richmond County, Georgia, 2009-2010 (aerial photograph taken about 2009). 


\section{Description of the Study Area}

Fort Gordon is located south of the Fall Line in the northern part of the Coastal Plain Physiographic Province near Augusta, Georgia (fig. 1). Fort Gordon is underlain by Cretaceous and Tertiary geologic strata and is characterized by surficial soils and sediments of unconsolidated sands and semi-consolidated sandstones, and layers of clay that include kaolinite (Hetrick, 1992; Gregory and others, 2001).

The FMPR is a flat, partially wooded, sandy area on a hilltop between two unnamed tributaries of Butler Creek (fig. 1). The site is bordered by sand roads on the eastern and southern sides, a low-relief sand berm and woodlands on the northern side, and woodlands on the western side (fig. 2). The southern half of the FMPR is covered with pines and minor underbrush, and the northern half is sparsely wooded with open sandy areas. No buildings or manmade structures, other than the low-relief berm, are currently (2011) present at the FMPR.

\section{Methods}

All samples were collected from the FMPR in May, August, and September 2010, and were analyzed by standard laboratory methods (U.S. Geological Survey, variously dated). The samples were collected for assessments of potential organic compounds in soil gas and inorganic constituents in soil as contaminants at the FMPR.

\section{Passive Soil-Gas Samplers}

The two passive soil-gas surveys were conducted at the FMPR by using the GORE ${ }^{\mathrm{TM}}$ passive soil-gas sampler, a commercially available passive soil-gas sampler based on GORE-TEX ${ }^{\mathrm{TM}}$ membrane technology (U.S. Environmental Protection Agency, 1998; W.L. Gore \& Associates, Inc., 2004; American Society for Testing and Materials, 2006). The sampler consists of proprietary adsorbent medium placed inside a shoestring-shaped GORE-TEX ${ }^{\mathrm{TM}}$ tube (fig. $3 A$ ). The passive soil-gas approach was approved for use at abandoned sites at Fort Gordon by the Hazardous Waste Management Branch, Georgia Environmental Protection Department (William Powell, P.E., Environmental Engineer, Department of Defense Remediation Unit, oral commun., December 10, 2008).

The adsorbent medium inside the GORE passive soil-gas sampler can adsorb a wide variety of volatile and semivolatile organic compounds (VOCs/SVOCs), including chlorinated solvents such as trichloroethene (TCE) and perchloroethylene (PCE; also known as tetrachloroethene); gasoline range compounds such as benzene, toluene, ethylbenzene, and xylenes (collectively referred to as BTEX); the gasoline additive methyl tert-butyl ether (MTBE); diesel range compounds (collectively referred to as $\mathrm{C}_{11}, \mathrm{C}_{13}$, and $\mathrm{C}_{15}$ ) such as undecane, tridecane, and pentadecane; and polycyclic aromatic hydrocarbons (PAHs) such as naphthalene. The adsorbent material also can adsorb organic compounds classified as chemical warfare agents, such as mustard gas and tear gas, and explosives, including nitrobenzene and nitrotoluene compounds.

Passive soil-gas results can indicate the presence of a particular organic compound and are a rapid approach for environmental assessment of organic compounds. The results do not, however, reveal if the detection was derived from free product, residual-phase compounds adsorbed on soil particles, vapors in the unsaturated zone, or the dissolved compound in shallow and deep groundwater (unless the passive soil-gas sampler is deployed in direct contact with water). In unsaturated soil, higher soil-gas mass in a sampler tends to be related to the presence of residual compounds or free product that is close to the land surface where the soil-gas sampler is located. If such source material is located at greater depths, however, the soil-gas mass generally will be lower. A lower value near known sources may be due to various attenuation processes that affect the soil-gas mass prior to detection. In both cases, however, the passive soil-gas samplers help to indicate the presence or absence of contaminants.

Sample sites for the soil-gas surveys in the study area were created with a stainless steel bit attached to a cordless drill (fig. 4). The bit was used to drill a vertical borehole in the soil with a diameter of 0.5 inch and a depth of 15 inches. A string is attached to a cork plug at one end and the passive soil-gas sampler at the other end, and is used to lower and suspend the sampler in the borehole. The cork plug sealed the borehole at land surface to prevent surface water and ambient land-surface material from entering the borehole. The depth of 15 inches is similar to the depth recommended by the U.S. Environmental Protection Agency (USEPA) for soil-gas investigations (U.S. Environmental Protection Agency, 1998). All soil-gas samplers were recovered after 4 to 5 days.

Each soil-gas sampler was recovered in the field and placed in its original 20-milliliter (mL) air-tight vial (fig. $3 B$ ), and sent to a commercial laboratory (W.L. Gore \& Associates, Inc.) for analysis. Some of the samplers were kept in the air-tight vials during the deployment and recovery of environmental samplers, and were shipped back to the laboratory with the environmental samplers as trip blanks.

All samplers were processed and analyzed at the laboratory by using a modification of USEPA method $8260 / 8270$ (U.S. Environmental Protection Agency, 2006). Prior to analysis, each sampler was processed in an automated thermal desorption unit to produce a VOC/SVOC gas sample. The gas sample was analyzed by gas chromatographs equipped with mass-selective detectors. The laboratory analyzed instrument and method blanks, in addition to the field blanks, for quality assurance and was in compliance with Good Laboratory Practices and ISO Guide 25 (International Organization for Standardization, 1990). Results are expressed as mass (micrograms) for all passive soil-gas samplers deployed in the unsaturated soil of the FMPR.

The laboratory results provided screening-level data for the assessment of 31 organic analytes. Results were used to calculate values for the combined masses of benzene, toluene, 


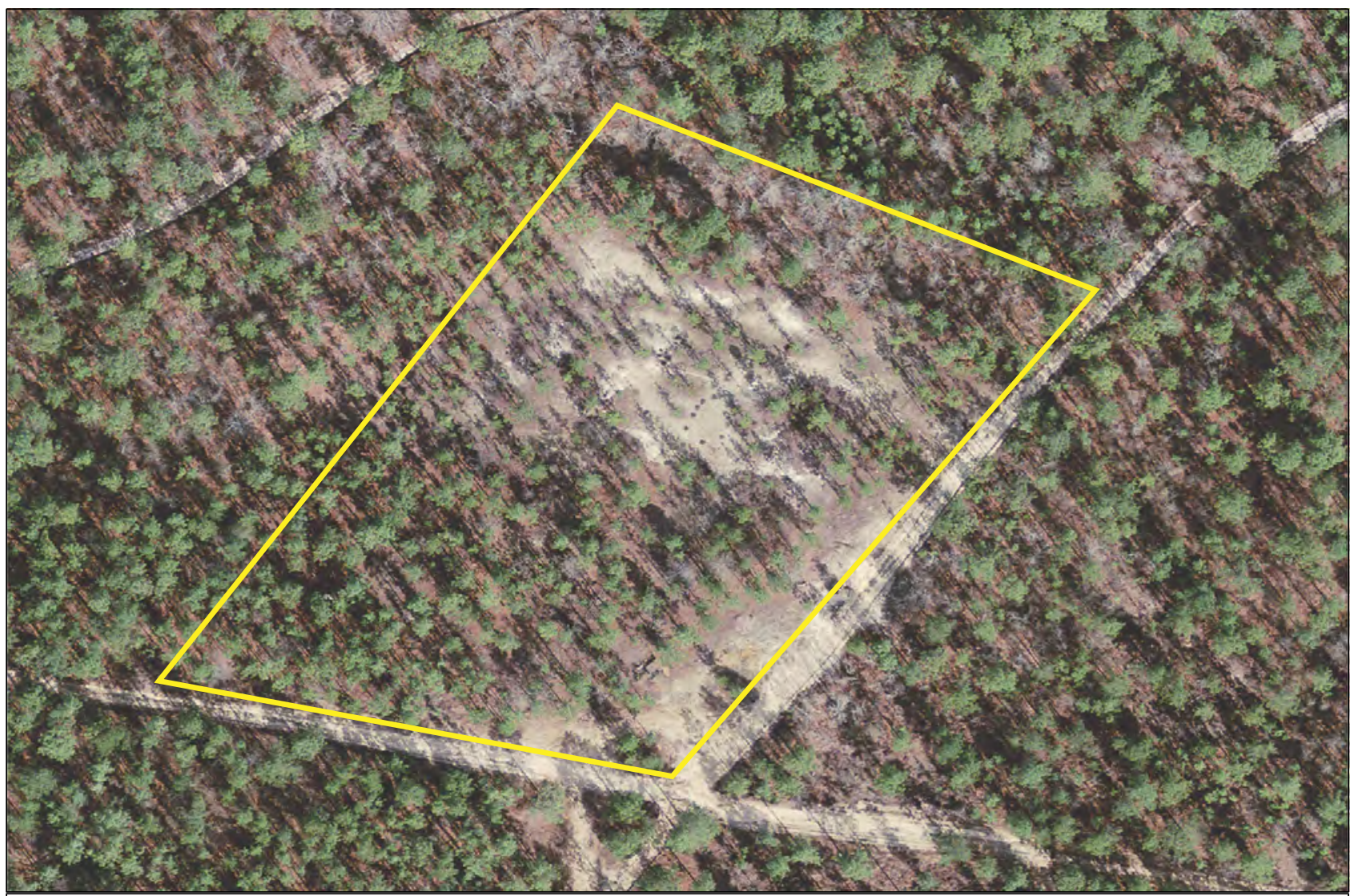

Photograph provided by Hagan Ratliff

Environmental Branch, Fort Gordon, Georgia

Written communication, December 15, 2010

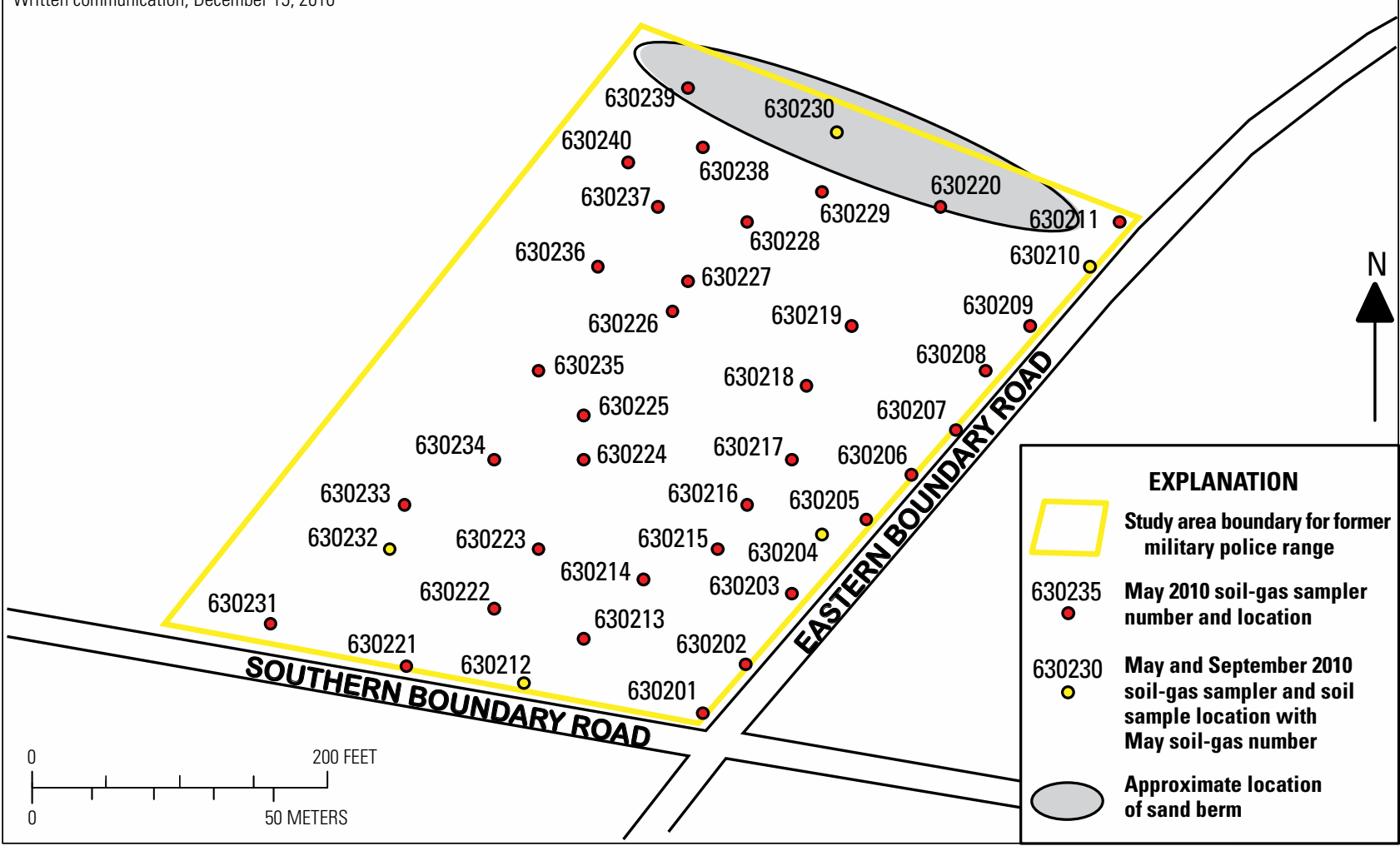

Figure 2. Locations of the former military police range study area and sampling sites at Fort Gordon in Richmond County, Georgia, 2009-2010. 
Figure 3. Soil-gas sampler (A) prior to being installed, and $(B)$ in air-tight vial for shipment from and to the laboratory for analysis.
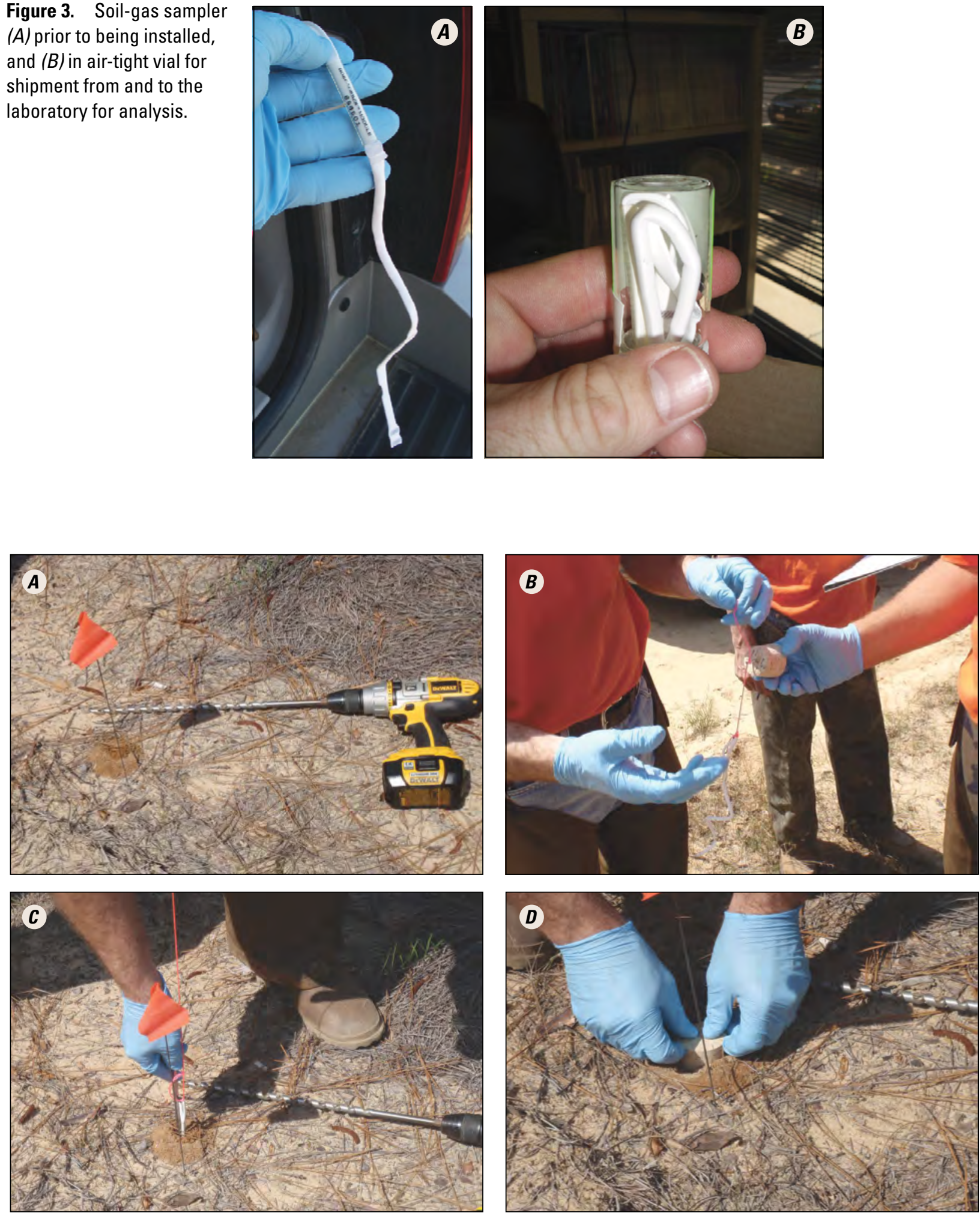

Figure 4. Installation of a passive soil-gas sampler includes $(A)$ drilling a borehole in the soil with a stainless steel drill bit attached to a cordless drill, $(B)$ attaching one end of a string to a sampler and the other end to a cork plug, $(C)$ inserting the sampler on the string into the borehole, and $(D)$ sealing the borehole with the cork plug to keep out surface contaminants. 
ethylbenzene, and xylenes (gasoline-range compounds) as BTEX; the combined masses of undecane, tridecane, and pentadecane (diesel-range alkanes) as $\mathrm{C}_{11}, \mathrm{C}_{13}$, and $\mathrm{C}_{15}$; the combined masses of 1,2,4- and 1,3,5- trimethylbenzene; the combined masses of trans- and cis-1,2-dichloroethene; and the combined masses of naphthalene and 2-methyl naphthalene. The laboratory provided method detection levels (MDL) for each of the 31 organic compounds, but did not provide MDLs for the combined masses. Total petroleum hydrocarbon (TPH) is one of the 31 organic analytes reported by the laboratory and is a laboratory-derived estimate based on the area under the chromatogram for all aliphatic hydrocarbons, including all gasoline-range ( $\mathrm{C} 4$ to $\mathrm{C} 10)$ and diesel-range (C10 to C20) compounds.

Forty soil-gas samplers were deployed on May 20, 2010, and recovered on May 24, 2010, to assess the presence for organic compounds at the FMPR (fig. 2). The samplers were deployed in a grid pattern to cover the generalized extent of the FMPR. Three additional soil-gas samplers, which served as trip blanks, were unopened during the May 2010 survey and shipped with the field samplers to the laboratory.

The results of the May 2010 soil-gas survey were used to select five sites at the FMPR for a September 2010 soilgas survey to evaluate the presence of organic compounds classified as chemical agents and explosives (fig. 2). The five soil-gas sites chosen for the September 2010 survey included four VOC-detection sites and one background site identified during the May 2010 soil-gas survey. These five soil-gas samplers were deployed on September 16, 2010, but only four were recovered on September 22, 2010. The sampler not recovered was located in the northeastern corner of the FMPR, at a site where organic compounds had been detected during the May 2010 soil-gas survey. The sample site for the lost sampler (644226) was found on September 22, but the sampler, string, and cork were missing. Two trip-blanks were sent to the laboratory with the samplers collected during the September 2010 survey. The samplers and trip-blanks were analyzed for 11 chemical agents and 9 explosives.

\section{Soil Samples}

Composite soil samples were collected on August 30, 2010, at the same five locations as in the September 2010 soil-gas survey (fig. 2). A stainless-steel hand auger was used to collect the samples from an interval between land surface and a depth of 6 inches (fig. 5). The auger was washed with a soap solution, rinsed with deionized water, and wiped with a paper towel before the collection of each sample.

The analysis of soil samples was conducted by using Inductively Coupled Plasma-Mass Spectrometry (ICP-MS; LaDonna Choate, Research Chemist, U.S. Geological Survey, Denver, Colorado, written commun., February 8, 2009). The

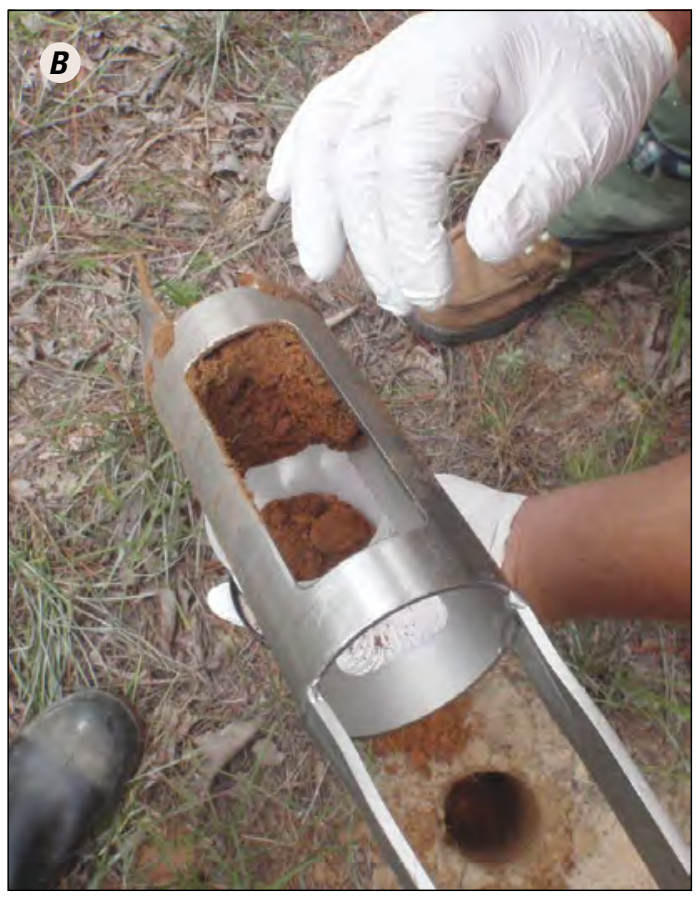

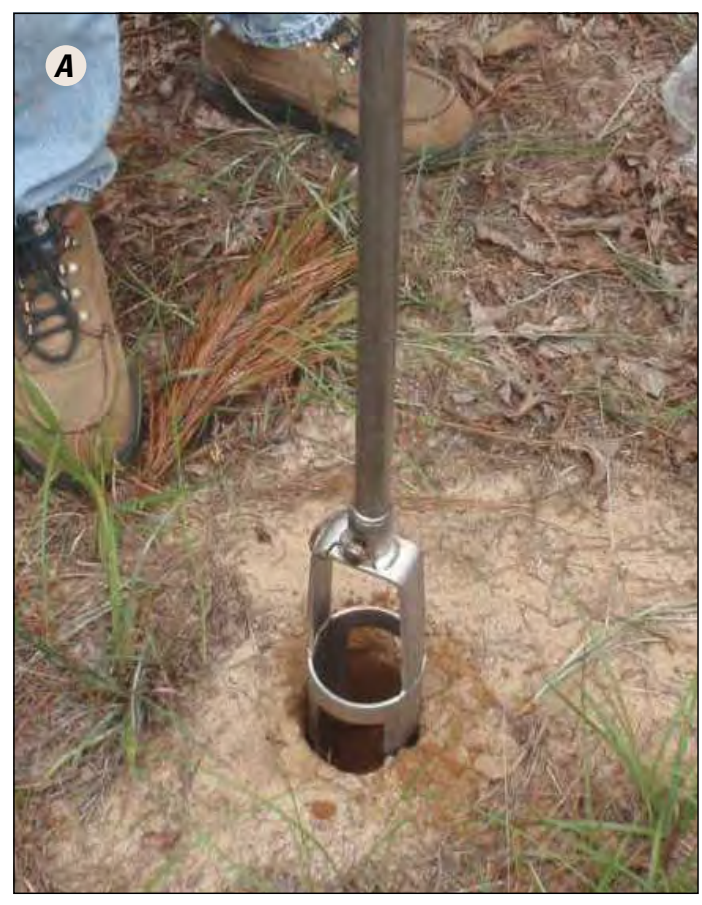

Figure 5. A soil sample $(A)$ collected with a stainless steel hand auger in the interval from land surface to a depth of 6 inches and $(B)$ transferred to a plastic container for shipment to the laboratory. 
soil samples were ground into a powder and processed by a multi-acid digestion technique prior to analysis (Crock and others, 1983). The multi-acid digestion technique combined with ICP-MS is suited for the analysis of metals in rocks, soils, and sediments (Briggs and Meier, 2002). Each sample was analyzed for 35 inorganic constituents.

\section{Results}

All soil-gas samplers were installed to the same depth at the FMPR. Therefore, a higher soil-gas mass for a particular contaminant generally indicates closer proximity to a contaminant source. For all soil-gas results, except for TPH, the detection of an organic compound above the MDL provided by the laboratory indicated an environmental contaminant. TPH results for the May 2010 soil-gas survey ranged from 0.05 to 0.54 microgram $(\mu \mathrm{g})$ in the three trip blanks and from 0.03 and $0.04 \mu \mathrm{g}$ in the two laboratory method blanks (see last page of table 1). All five blanks exceeded the laboratory MDL of $0.02 \mu \mathrm{g}$ for TPH and required censoring of the results being discussed as detections. Only TPH detections with masses that are one order of magnitude or greater than the highest mass detected in the blanks $(0.54 \mu \mathrm{g})$ are shown in figure 6 , and are presumed to represent detections of environmental contaminants at the FMPR. No other compounds were detected in the trip and method blanks.

\section{Passive Soil-Gas Samplers}

The May soil-gas survey for VOCs at the FMPR detected mostly gasoline and diesel compounds. Most of the higher soil-gas masses as TPH, BTEX, and diesel were identified in the southwestern quarter of the FMPR and along the eastern boundary road (figs. 6-8). Most of the higher soil-gas masses for chloroform were identified in the southern half of the FMPR (fig. 9). The survey identified a detection of PCE (tetrachloroethene) above the MDL of $0.02 \mu \mathrm{g}$ in sampler 630212 near the southern boundary road.

All soil-gas samplers recovered for the May 2010 survey detected TPH concentrations greater than the MDL of $0.02 \mu \mathrm{g}$ (fig. 6; table 1). Only masses greater than $10 \mu \mathrm{g}$ are discussed as environmental contaminants because of TPH concentrations detected in trip blanks. The highest soil-gas TPH mass of $41.85 \mu \mathrm{g}$ was reported at sampler 630232 in the southwestern quarter of the FMPR where five more samplers also detected TPH masses ranging from 12 to $40 \mu \mathrm{g}$. Soil-gas TPH mass ranged from 11 to $36 \mu \mathrm{g}$ in three samplers deployed in the northwestern quarter and from 28 to $39 \mu \mathrm{g}$ in three samplers deployed adjacent to the eastern boundary road of the FMPR. A mass of $37 \mu \mathrm{g}$ was detected in sampler 630215 deployed in the southeastern quarter of the FMPR (figs. 2, 6).

Detections of BTEX were greater than $0.02 \mu \mathrm{g}$ in nine soil-gas samplers deployed at the FMPR and ranged from 0.07 to $0.12 \mu \mathrm{g}$ in four samplers deployed in the southwestern quarter of the FMPR (fig. 7; table 1). Additionally, BTEX detections ranged from 0.03 to $0.07 \mu \mathrm{g}$ in three samplers deployed adjacent to the eastern boundary road. All nine samplers with BTEX detections coincided with TPH detections of greater than $10 \mu \mathrm{g}$ in the FMPR (figs. 6, 7). Toluene was the only BTEX component specifically identified in the May 2010 survey and accounts for the total BTEX mass reported in all nine soil-gas samplers.

Six detections of diesel compounds exceeded MDLs in five soil-gas samplers at the FMPR (fig. 8; table 1). The two highest diesel detections were in samplers 630211 and 630215 with mass of 0.11 and $0.12 \mu \mathrm{g}$. Detections of undecane exceeded the MDL of $0.04 \mu \mathrm{g}$ in three samplers. The three undecane detections coincided with three of the higher soil-gas masses of TPH, including samplers 630210 and 630211 in the northeastern corner and sampler 630215 in the southeastern quarter of the FMPR (fig. 2). Tridecane exceeded the MDL of $0.02 \mu \mathrm{g}$ in sampler 630221 in the southwestern quarter of the FMPR where TPH was detected. Pentadecane also exceeded the MDL of $0.02 \mu \mathrm{g}$ in the southwestern quarter of the FMPR along with tridecane in sampler 630221 and was the only diesel compound detected in sampler 630232.

None of the soil-gas samplers had detections of chlorinated or aromatic organic compounds exceeding MDLs, except for 10 soil-gas samplers with chloroform detections greater than the MDL of $0.02 \mu \mathrm{g}$ and a detection of PCE (tetrachloroethene) exceeding the MDLs of $0.02 \mu \mathrm{g}$ (fig. 9; table 1). Most of the soil-gas samplers with chloroform detections were located in the southern half of the FMPR, with only two exceptions in the northern half of the study area (samplers 630210 and 630229, fig. 2). The only detection of PCE was in sampler 630212, which is adjacent to the southern boundary road. No other organic compounds were detected in this sampler except for a low soil-gas TPH mass of $2.7 \mu \mathrm{g}$.

No organic compounds classified as explosives or chemical agents were detected above MDLs in the four soilgas samplers recovered during the September 2010 survey at the FMPR (fig. 10; table 2). Results for a few compounds were reported as below detection level (bdl) which means the mass of the compound was below the method detection level and could not be quantified. In such cases, the laboratory cannot report the mass with the same certainty as a detection above the method detection level. 


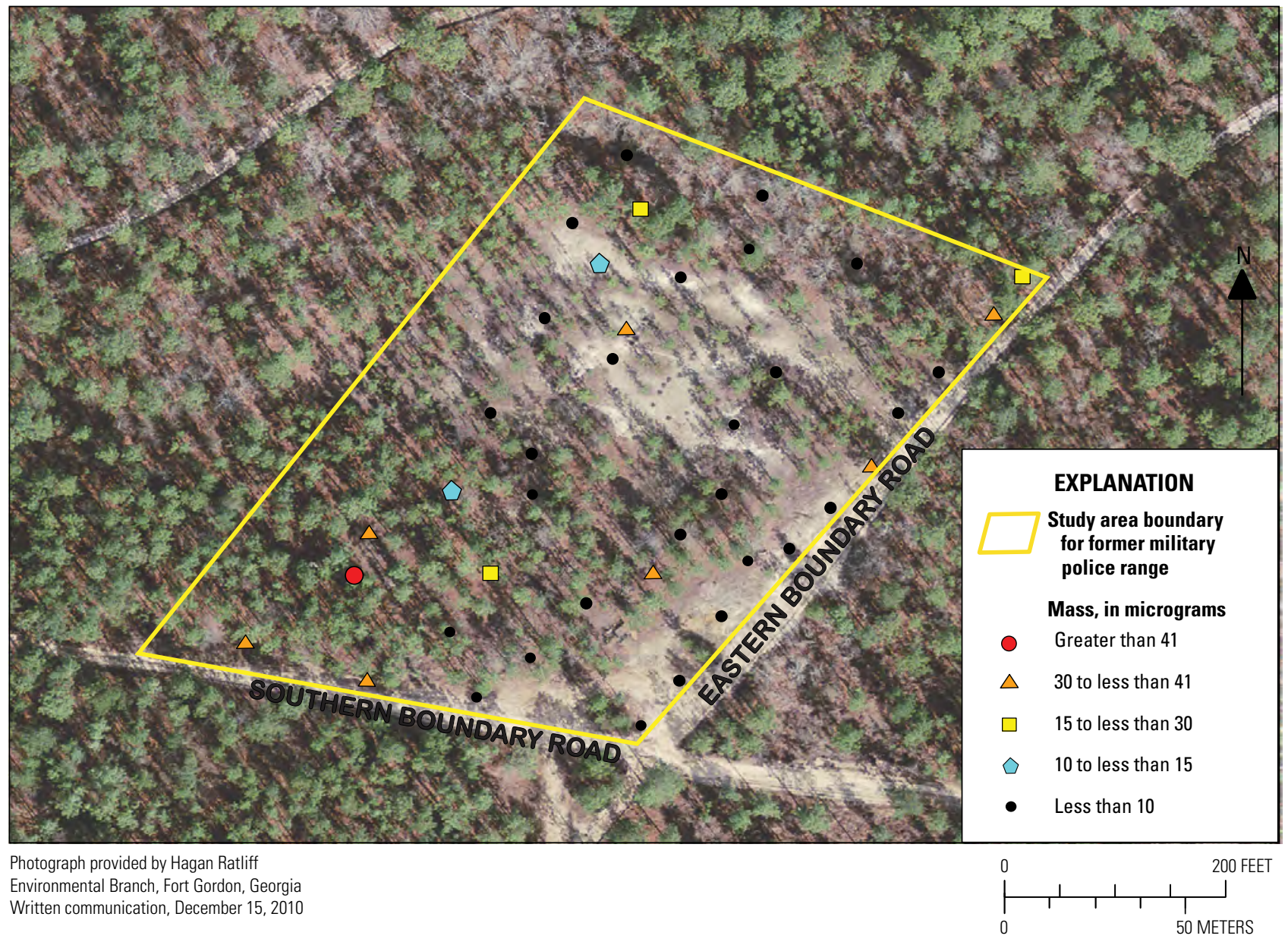

Figure 6. Total petroleum hydrocarbon (TPH) mass in soil-gas samplers, former military police range, Fort Gordon, Georgia, May 20-24, 2010. Method detection level is 0.02 microgram; TPH was, however, detected in trip and method blanks. All TPH data, therefore, were censored at 10 micrograms. 


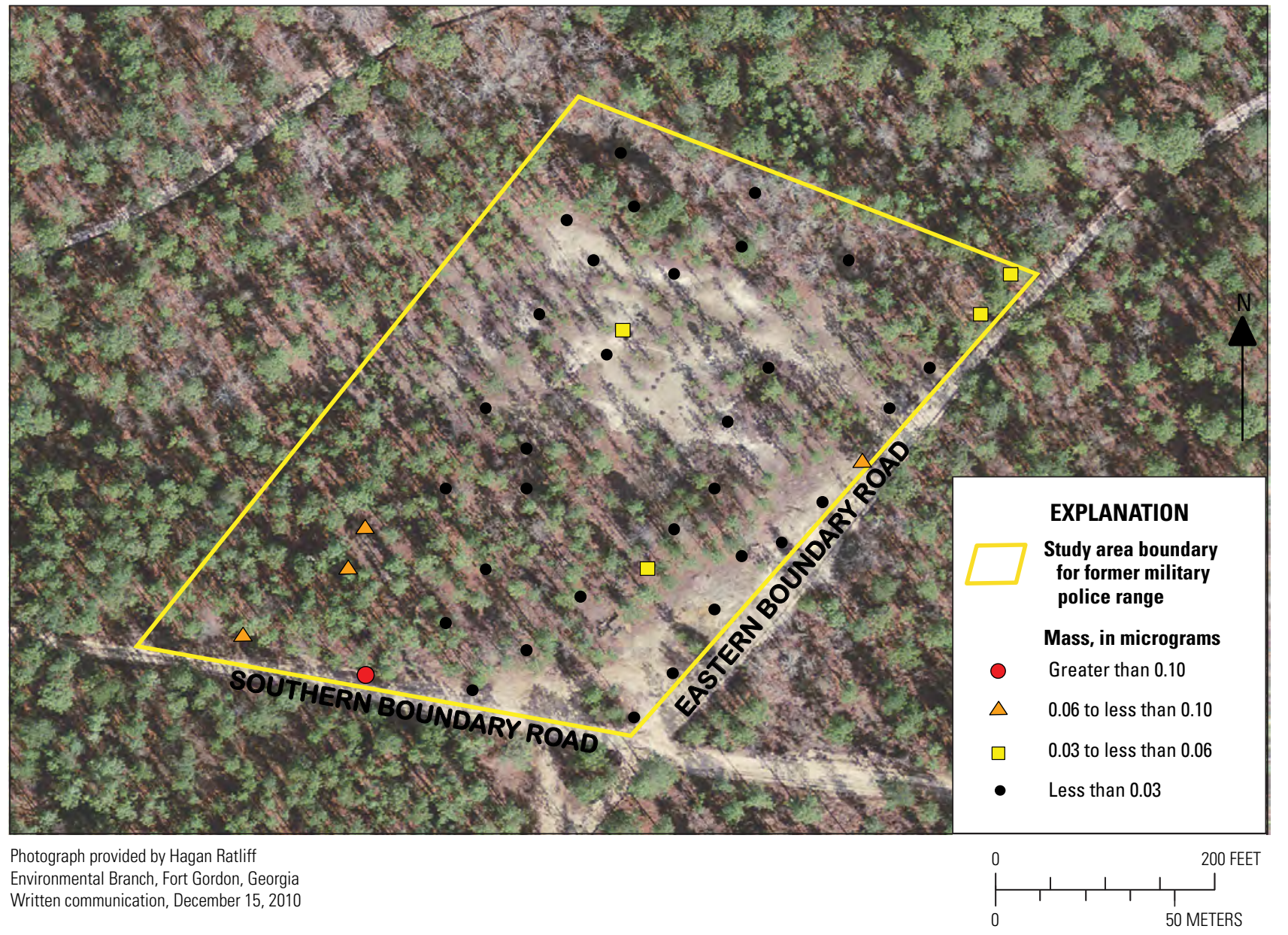

Figure 7. Combined benzene, toluene, ethylbenzene, and xylene (gasoline) masses as BTEX in soil-gas samplers, former military police range, Fort Gordon, Georgia, May 20-24, 2010. Method detection level for toluene equals 0.02 microgram. Benzene, ethylbenzene, and xylene did not exceed method detection levels. All combined masses, therefore, were censored at less than 0.03 microgram. 


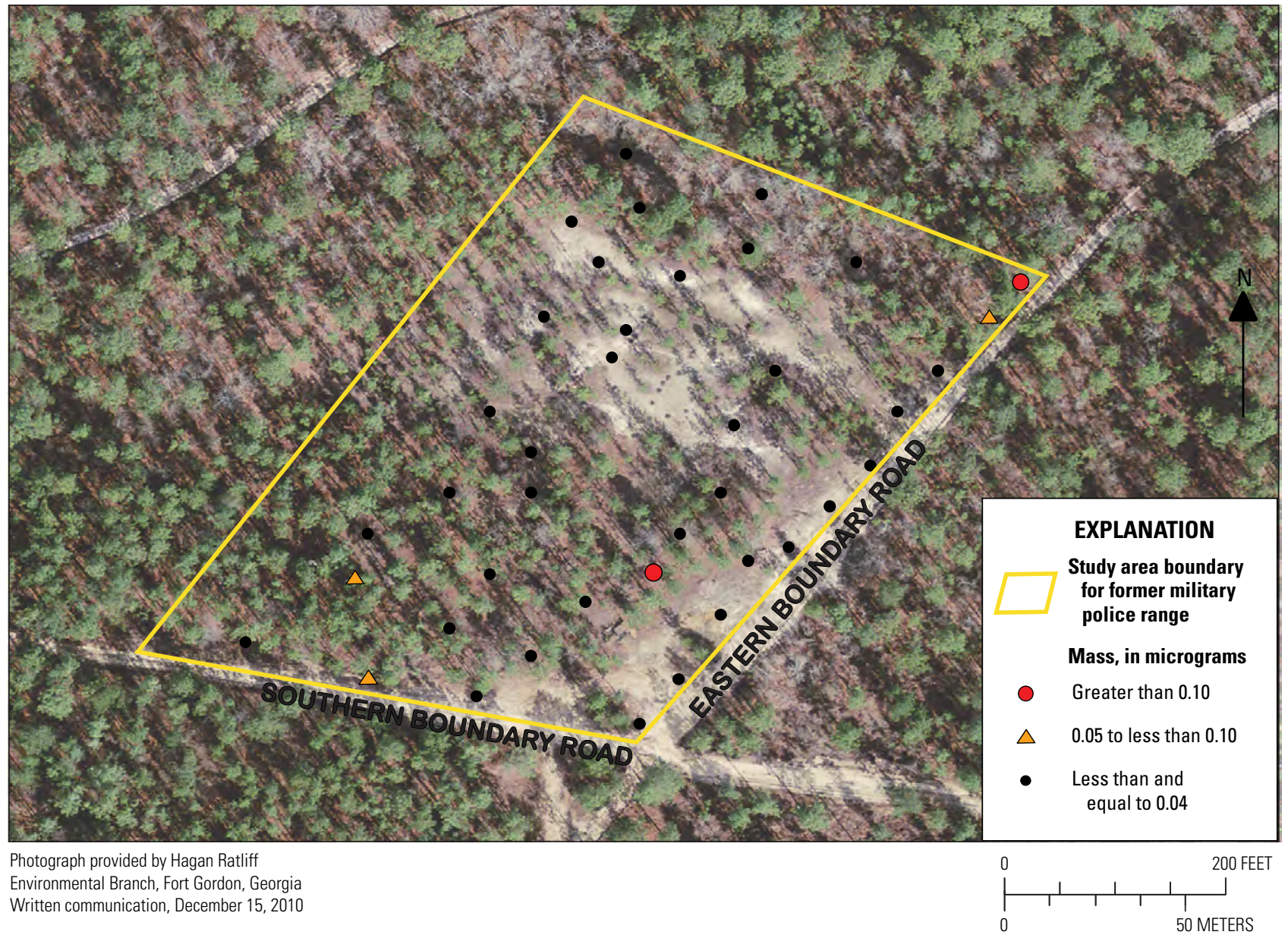

Figure 8. Combined undecane, tridecane, and pentadecane (diesel) masses in soil-gas samplers, former military police range, Fort Gordon, Georgia, May 20-24, 2010. Method detection levels for undecane, tridecane, and pentadecane ranged from 0.02 to 0.04 microgram. All combined masses were censored at 0.04 microgram. 


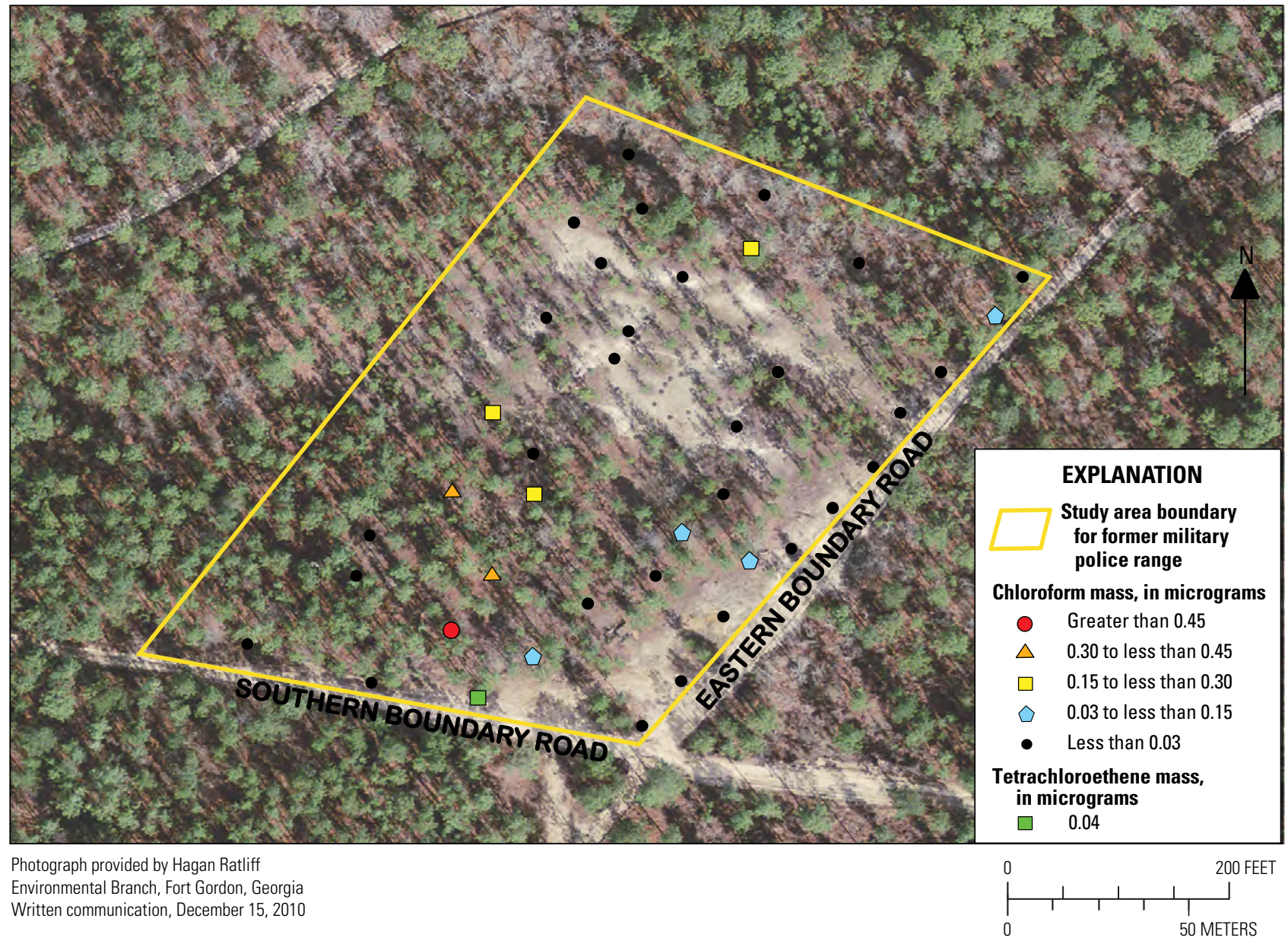

Figure 9. Chloroform and tetrachloroethene masses in soil-gas samplers, former military police range, Fort Gordon, Georgia, May 20-24, 2010. Method detection levels are 0.02 microgram for both analytes. 


\section{Soil Samples}

Composite soil samples were collected at five sampling locations in the FMPR. Four sampling locations are characterized by VOC soil-gas contaminants (fig. 10). Soil sample 1 collected at the same location as May 2010 soil-gas sampler 650204 had minimal organic detections and served as an example of a relatively uncontaminated soil sample in the FMPR study area for comparison to soil samples 2 through 5. The samples were analyzed for 35 inorganic constituents, including six of the eight RCRA metals (selenium and mercury were excluded). Soil-sample inorganic concentrations were compared to the USEPA regional screening levels (RSLs) for industrial soil (U.S. Environmental Protection Agency, 2009; table 3). Concentrations for 19 of the 35 constituents in table 3 also were compared to ambient, uncontaminated (background) levels for soils in the adjacent State of South Carolina (South Carolina Department of Health and Environmental Control, 2002) because no similar background levels were available for Georgia. The comparison was valid because Georgia and South Carolina are composed of similar geologic strata in the Coastal Plain Physiographic Provinces.

At all five locations, inorganic concentrations in soil samples did not exceed the USEPA RSLs and were generally less than background concentrations reported for similar Coastal Plain sediments in South Carolina (table 3). Barium concentrations for two samples in the southern half of the FMPR were, however, slightly greater than, but close to, a background concentration of 38 milligrams per kilogram.

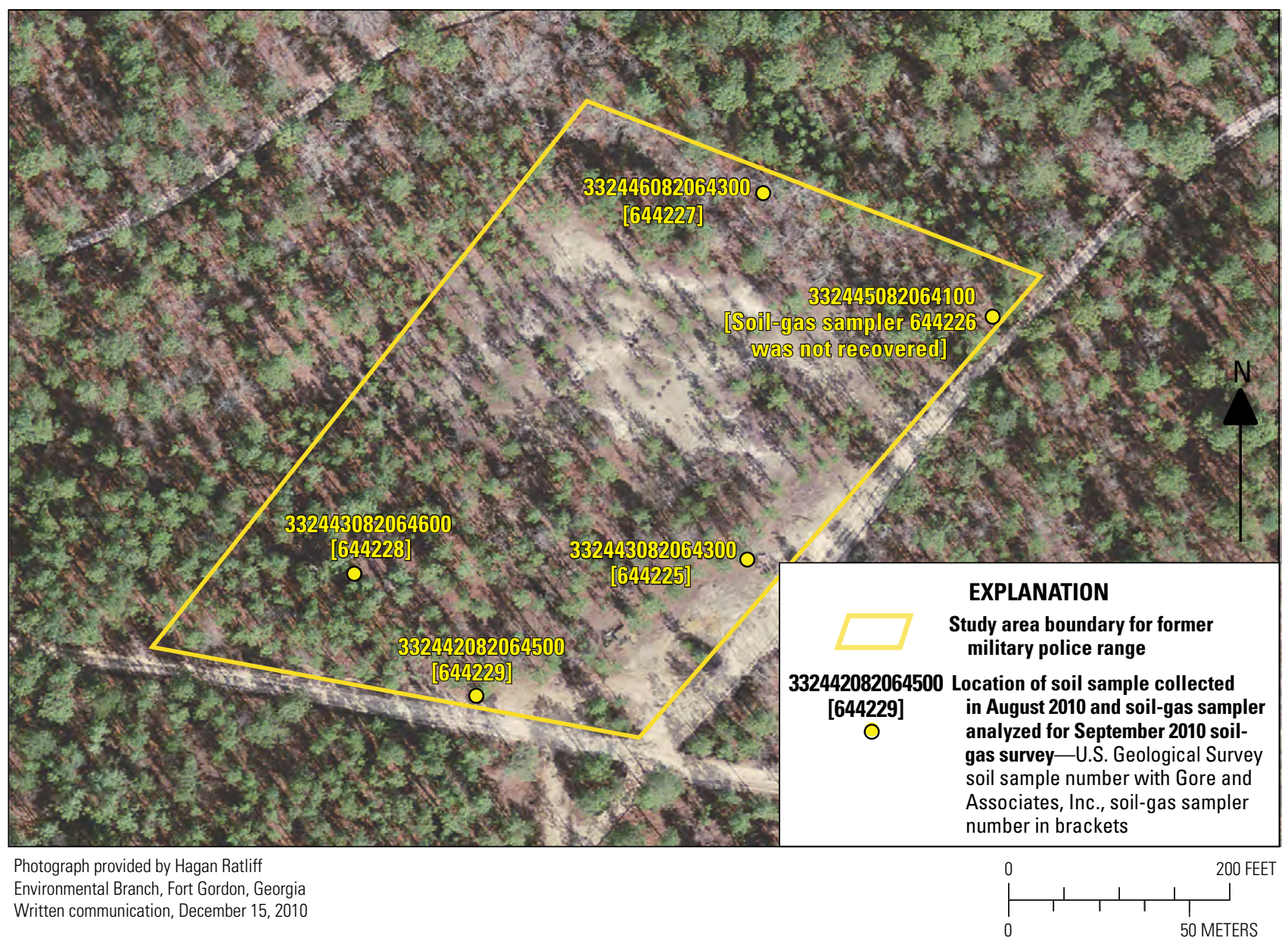

Figure 10. Locations of soil-gas samplers analyzed for organic compounds classified as explosives and chemical agents, September 15-22, 2010, and soil samples analyzed for inorganic constituents, August 30, 2010, former military police range, Fort Gordon, Georgia, 2009-2010. 


\section{Summary}

The U.S. Geological Survey, in cooperation with the Environmental and Natural Resources Management Office of the U.S. Army Signal Center and Fort Gordon, Georgia, assessed soil gas and soil for contaminants at the former military police range at Fort Gordon, Georgia, from May to September 2010. The 40 soil-gas samplers deployed in the May 2010 survey were analyzed for 31 organic compounds classified as volatile organic compounds and semivolatile organic compounds. Of the five soil-gas samplers deployed in the September 2010 survey, four samplers were recovered and analyzed for organic compounds classified as chemical agents and explosives, but none of these analytes were detected above method detection levels. Five soil samples were collected for inorganic constituents.

Soil-gas samplers collected within localized areas during the May 2010 survey had elevated mass above the method detection level (MDL) for total petroleum hydrocarbons, gasoline- and diesel-range compounds, and chloroform. Six of the 13 samplers with total petroleum hydrocarbons greater than 10 micrograms $(\mu \mathrm{g})$ were collected in the southwestern corner of the site. The southwestern quarter also had half of the gasoline detections and two of the five diesel detections. Two samplers in the northeastern most corner next to the eastern boundary road also had detections of total petroleum hydrocarbons, gasoline, and diesel. Three samplers collected in the northwestern quarter of the site had detections of total petroleum hydrocarbons greater than $20 \mu \mathrm{g}$. Six detections of diesel compounds exceeded MDLs in five soil-gas samplers at the former military police range. Most of the chloroform detections exceeded soil-gas mass of greater than $0.02 \mu \mathrm{g}$ were detected in the southern half of the site. One soil-gas sampler deployed adjacent to the southern boundary road had a mass of tetrachloroethene greater than, but close to, the method detection levels.

Five soil samples were collected and analyzed for inorganic constituents. Concentrations in all five soil samples did not exceed the U.S. Environmental Protection Agency Regional Screening Level for industrial soil and were at or below background levels for similar rocks and strata in South Carolina.

\section{References Cited}

American Society for Testing and Materials, 2006, Standard guide for soil gas monitoring in the vadose zone: West Conshohocken, PA, ASTM D5314-92, 36 p.

Briggs, P.H., and Meier, A.L., 2002, The determination of forty-two elements in geological materials by inductively coupled plasma-mass spectrometry, in Taggart, J.E. Jr., ed., Analytical methods for chemical analysis of geologic and other materials, U.S. Geological Survey: U.S. Geological Survey Open-File Report 02-223, chapter I, 20 p.
Crock, J.G., Lichte, F.L., and Briggs, P.H., 1983, Determination of elements in National Bureau of Standards geological materials SRM 278 obsidian and SRM 688 basalt by inductively coupled plasma-atomic emission spectroscopy: Geostandards Newsletter, v. 7, no. 2, p. 335-340.

Gregory, M.B., Stamey, T.C., and Wellborn, J.B., 2001, Ecological characterization of streams, and fish-tissue analysis for mercury and lead at selected locations, Fort Gordon, Georgia, June 1999 to May 2000: U.S. Geological Survey Open-File Report 01-203, 14 p.

Hetrick, J.H., 1992, A geologic atlas of the Wrens-Augusta area: Georgia Geologic Survey Geologic Atlas no. 8, 2 plates.

International Organization for Standardization, 1990, ISO Guide 25. General requirements for the competence of calibration and testing laboratories (3d ed.): New York, American National Standards Institute.

South Carolina Department of Health and Environmental Control, 2002, Environmental Surveillance and Oversight Program data report, 2002, accessed February 11, 2010, at http://www.scdhec.gov/environment/envserv/docs/esop datarpt_02.pdf.

U.S. Environmental Protection Agency, 1998, Innovative Technology Verification Report Soil Gas Sampling Technology: EPA/600/R-98/095.

U.S. Environmental Protection Agency, 2006, The method of evaluating solid waste-Physical chemical methods (3d ed.), final update IV of SW846: Washington, D.C., EPA SW-846, January 3, 2008, information available on the Web, accessed March 22, 2010, at http://www.epa.gov/fedrgstr/ EPA-WASTE/2008/January/Day-03/f25575.htm.

U.S. Environmental Protection Agency, 2009, Regional screening level tables, accessed January 12, 2010, at http://www.epa.gov/reg3hwmd/risk/human/ rb-concentration_table/Generic_Tables/index.htm.

U.S. Geological Survey, variously dated, National field manual for the collection of water-quality data: U.S. Geological Survey Techniques of Water-Resource Investigation, book 9, chaps. A1-A9, accessed September 1, 2010, at http://pubs.water.usgs.gov/twri9A.

Williams, L.J., 2007, Hydrogeology and potentiometric surface of the Dublin and Midville aquifer systems in Richmond County, Georgia, January 2007: U.S. Geological Survey Scientific Investigations Map 2982, 1 sheet.

W.L. Gore \& Associates, Inc., 2004, GORE ${ }^{\mathrm{TM}}$ surveys for site assessment \& monitoring, accessed February 24, 2011, at http://www.gore.com/MungoBlobs/239/659/surveys_ environmental_brochure.pdf. 

Tables 1-3 
Table 1. Mass of volatile and semivolatile organic compounds detected in soil-gas samplers deployed and collected from the former military police range, Fort Gordon, Georgia, May 20-24, 2010.

[MDL, method detection level; $\mu \mathrm{g}$, microgram; NA, not applicable; nd, not detected; bdl, below detection level; samplers 630241, 630242, and 630243 are trip blanks]

\begin{tabular}{|c|c|c|c|c|c|c|c|c|}
\hline Organic compound & $\begin{array}{c}\text { MDL } \\
(\mu g)\end{array}$ & $\begin{array}{c}\text { Sampler } \\
630201\end{array}$ & $\begin{array}{c}\text { Sampler } \\
630202\end{array}$ & $\begin{array}{c}\text { Sampler } \\
630203\end{array}$ & $\begin{array}{c}\text { Sampler } \\
630204\end{array}$ & $\begin{array}{c}\text { Sampler } \\
630205\end{array}$ & $\begin{array}{c}\text { Sampler } \\
630206\end{array}$ & $\begin{array}{c}\text { Sampler } \\
630207\end{array}$ \\
\hline Total petroleum hydrocarbon (TPH) & 0.02 & 8.29 & 0.73 & 0.73 & 0.59 & 0.80 & 0.71 & 38.86 \\
\hline Benzene & 0.02 & nd & nd & nd & nd & nd & nd & nd \\
\hline Toluene & 0.02 & nd & nd & nd & nd & nd & nd & 0.07 \\
\hline$o$-Xylene & 0.02 & nd & nd & nd & nd & nd & nd & nd \\
\hline $\mathrm{C}_{11}, \mathrm{C}_{13}$, and $\mathrm{C}_{15}$ (diesel) & NA & 0.00 & nd & nd & nd & nd & nd & 0.00 \\
\hline Undecane & 0.04 & nd & nd & nd & nd & nd & nd & nd \\
\hline Tridecane & 0.02 & nd & nd & nd & nd & nd & nd & nd \\
\hline Trimethylbenzene & NA & nd & nd & nd & nd & nd & nd & nd \\
\hline 1,2,4-Trimethylbenzene & 0.02 & nd & nd & nd & nd & nd & nd & nd \\
\hline 1,3,5-Trimethylbenzene & 0.03 & nd & nd & nd & nd & nd & nd & nd \\
\hline 1,2-Dichlorobenzene & 0.02 & nd & nd & nd & nd & nd & nd & nd \\
\hline 1,3-Dichlorobenzene & 0.02 & nd & nd & nd & nd & nd & nd & nd \\
\hline 1,4-Dichlorobenzene & 0.02 & nd & nd & nd & nd & nd & nd & nd \\
\hline Chlorobenzene & 0.02 & nd & nd & nd & nd & nd & nd & nd \\
\hline Chloroform & 0.02 & nd & nd & nd & 0.05 & nd & nd & nd \\
\hline cis- and trans-1,2-Dichloroethene & NA & nd & nd & nd & nd & nd & nd & nd \\
\hline 1,1,1-Trichloroethane & 0.03 & nd & nd & nd & nd & nd & nd & nd \\
\hline 1,1,2-Trichloroethane & 0.02 & nd & nd & nd & nd & nd & nd & nd \\
\hline 1,1,1,2-Tetrachloroethane & 0.03 & nd & nd & nd & nd & nd & nd & nd \\
\hline 1,1,2,2-Tetrachloroethane & 0.02 & nd & nd & nd & nd & nd & nd & nd \\
\hline Carbon tetrachloride & 0.03 & nd & nd & nd & nd & nd & nd & nd \\
\hline Naphthalene and 2-Methyl naphthalene & NA & nd & nd & nd & nd & nd & nd & nd \\
\hline Naphthalene & 0.02 & nd & nd & nd & nd & nd & nd & nd \\
\hline 2-Methyl naphthalene & 0.02 & nd & nd & nd & nd & nd & nd & nd \\
\hline
\end{tabular}


Table 1. Mass of volatile and semivolatile organic compounds detected in soil-gas samplers deployed and collected from the former military police range, Fort Gordon, Georgia, May 20-24, 2010.-Continued

[MDL, method detection level; $\mu \mathrm{g}$, microgram; NA, not applicable; nd, not detected; bdl, below detection level; samplers 630241, 630242, and 630243 are trip blanks]

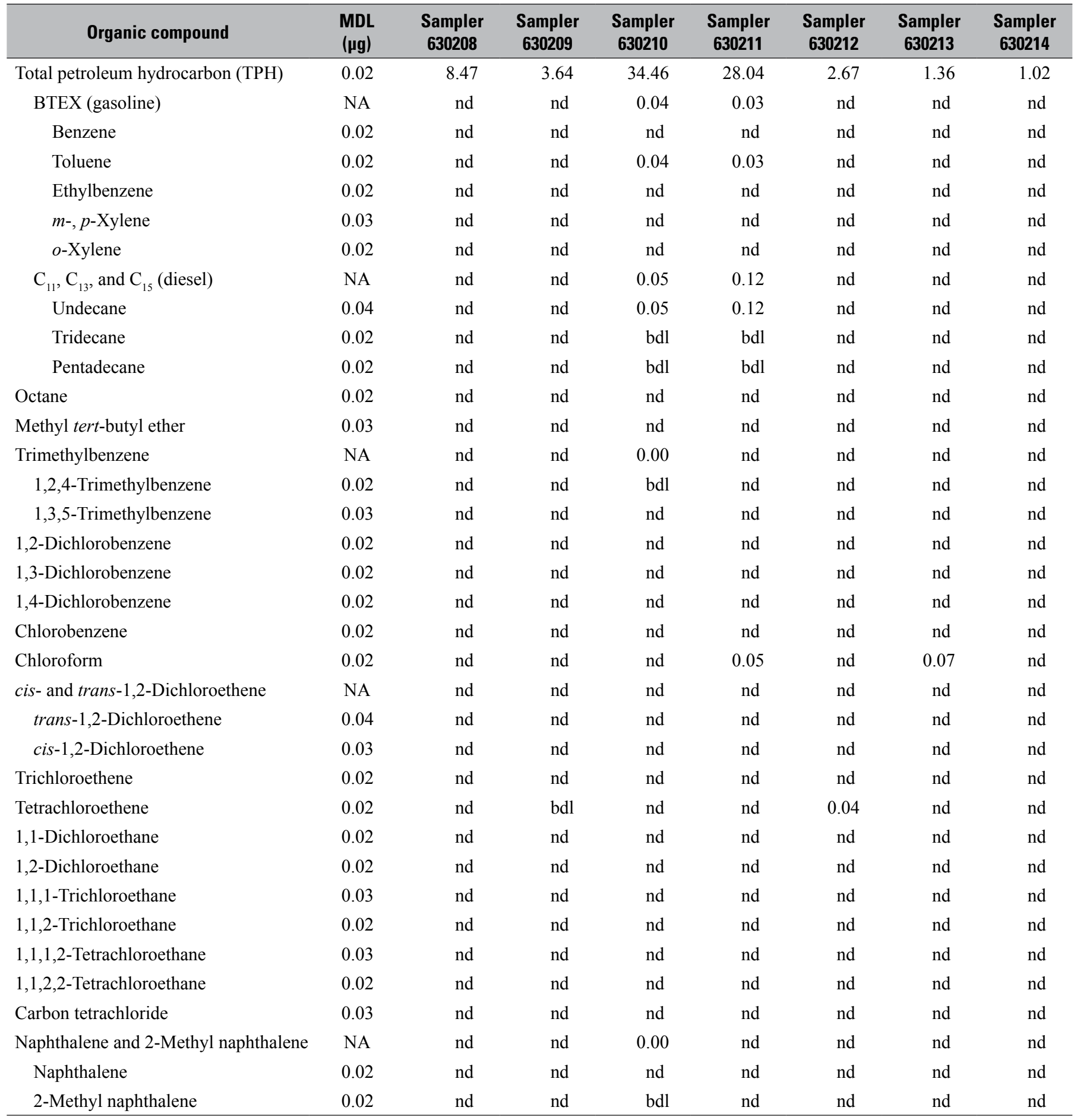


Table 1. Mass of volatile and semivolatile organic compounds detected in soil-gas samplers deployed and collected from the former military police range, Fort Gordon, Georgia, May 20-24, 2010.-Continued

[MDL, method detection level; $\mu \mathrm{g}$, microgram; NA, not applicable; nd, not detected; bdl, below detection level; samplers 630241, 630242, and 630243 are trip blanks]

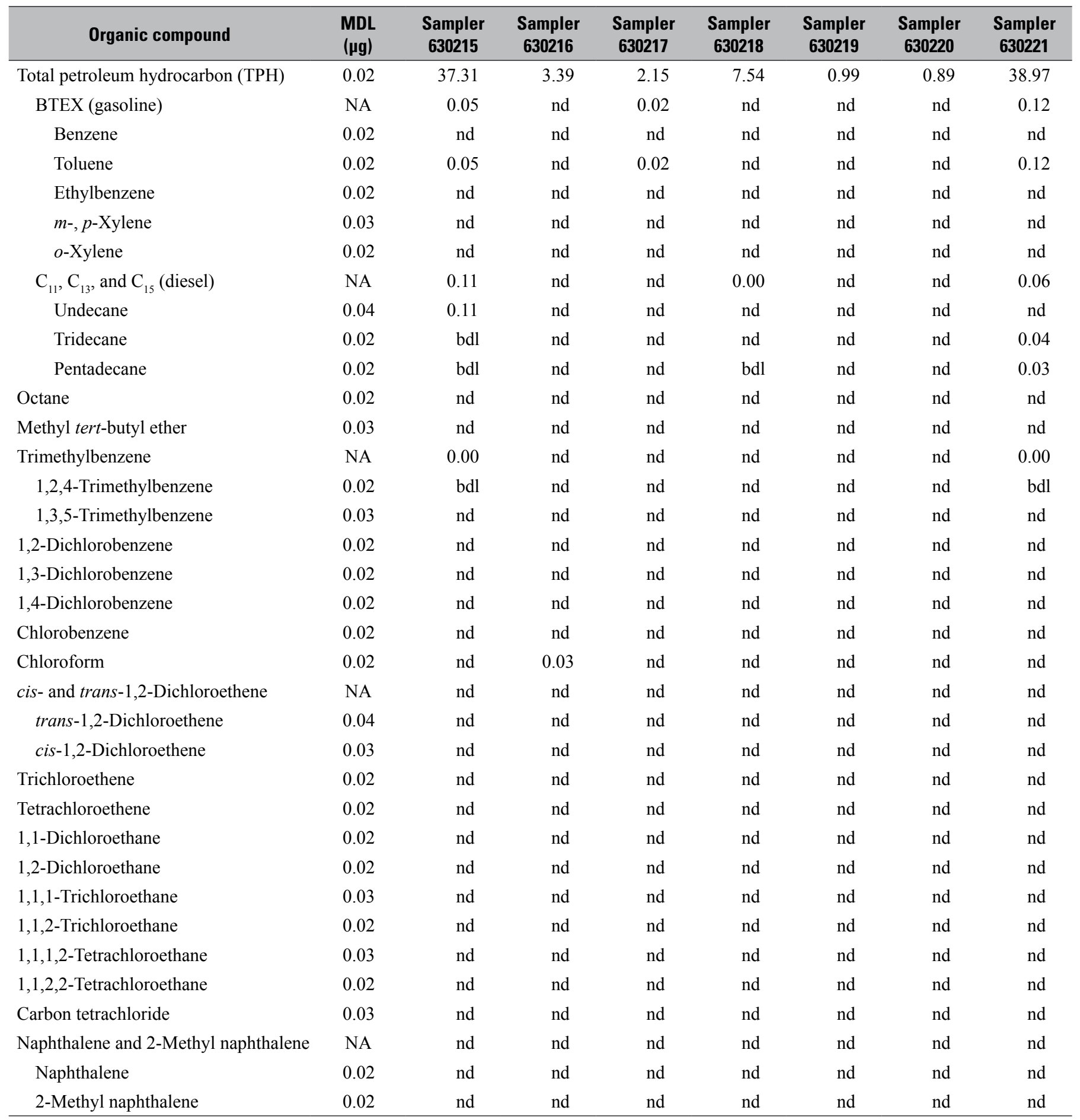


Table 1. Mass of volatile and semivolatile organic compounds detected in soil-gas samplers deployed and collected from the former military police range, Fort Gordon, Georgia, May 20-24, 2010.-Continued

[MDL, method detection level; $\mu \mathrm{g}$, microgram; NA, not applicable; nd, not detected; bdl, below detection level; samplers 630241, 630242, and 630243 are trip blanks]

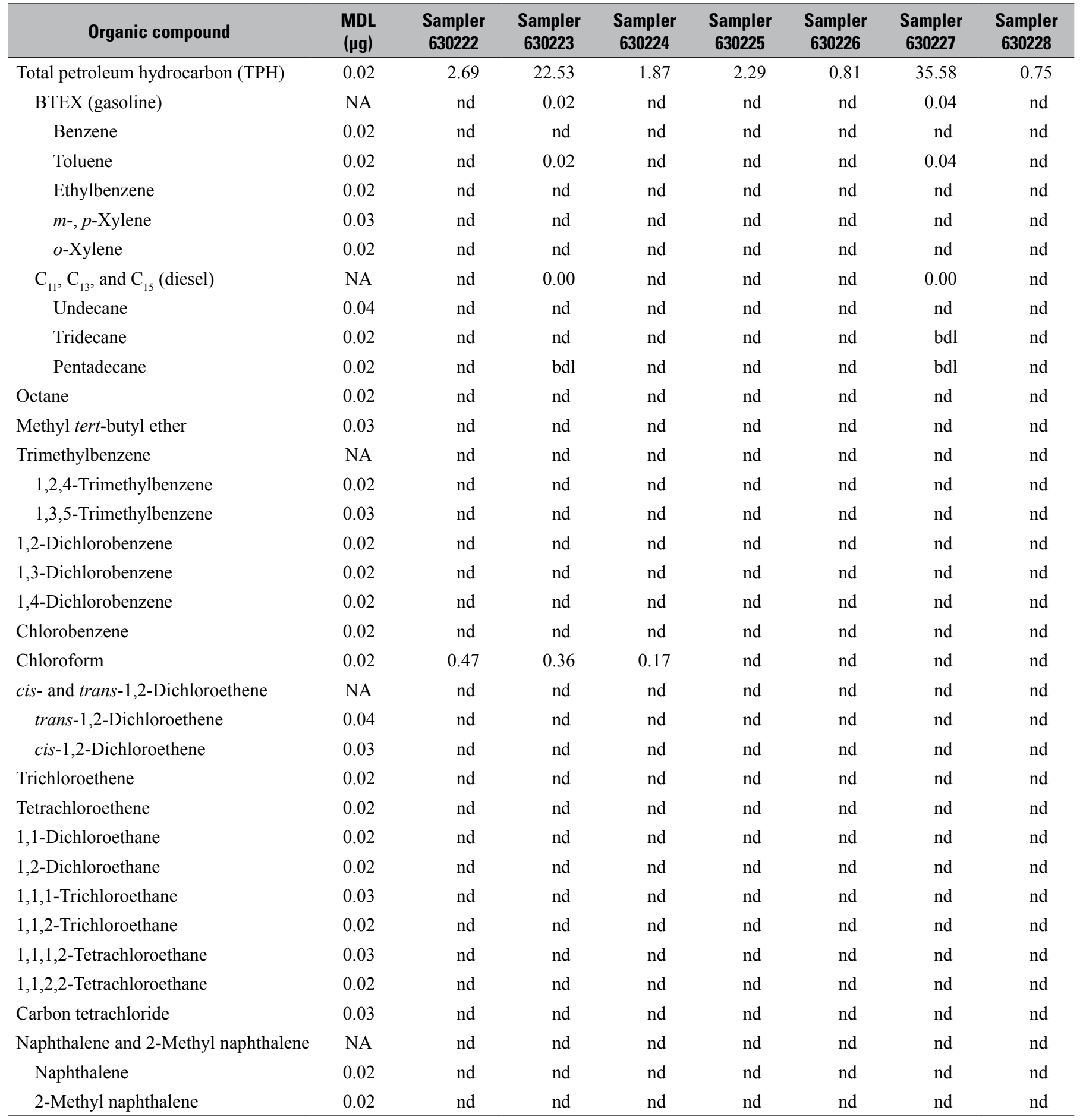


Table 1. Mass of volatile and semivolatile organic compounds detected in soil-gas samplers deployed and collected from the former military police range, Fort Gordon, Georgia, May 20-24, 2010.-Continued

[MDL, method detection level; $\mu \mathrm{g}$, microgram; NA, not applicable; nd, not detected; bdl, below detection level; samplers 630241, 630242, and 630243 are trip blanks]

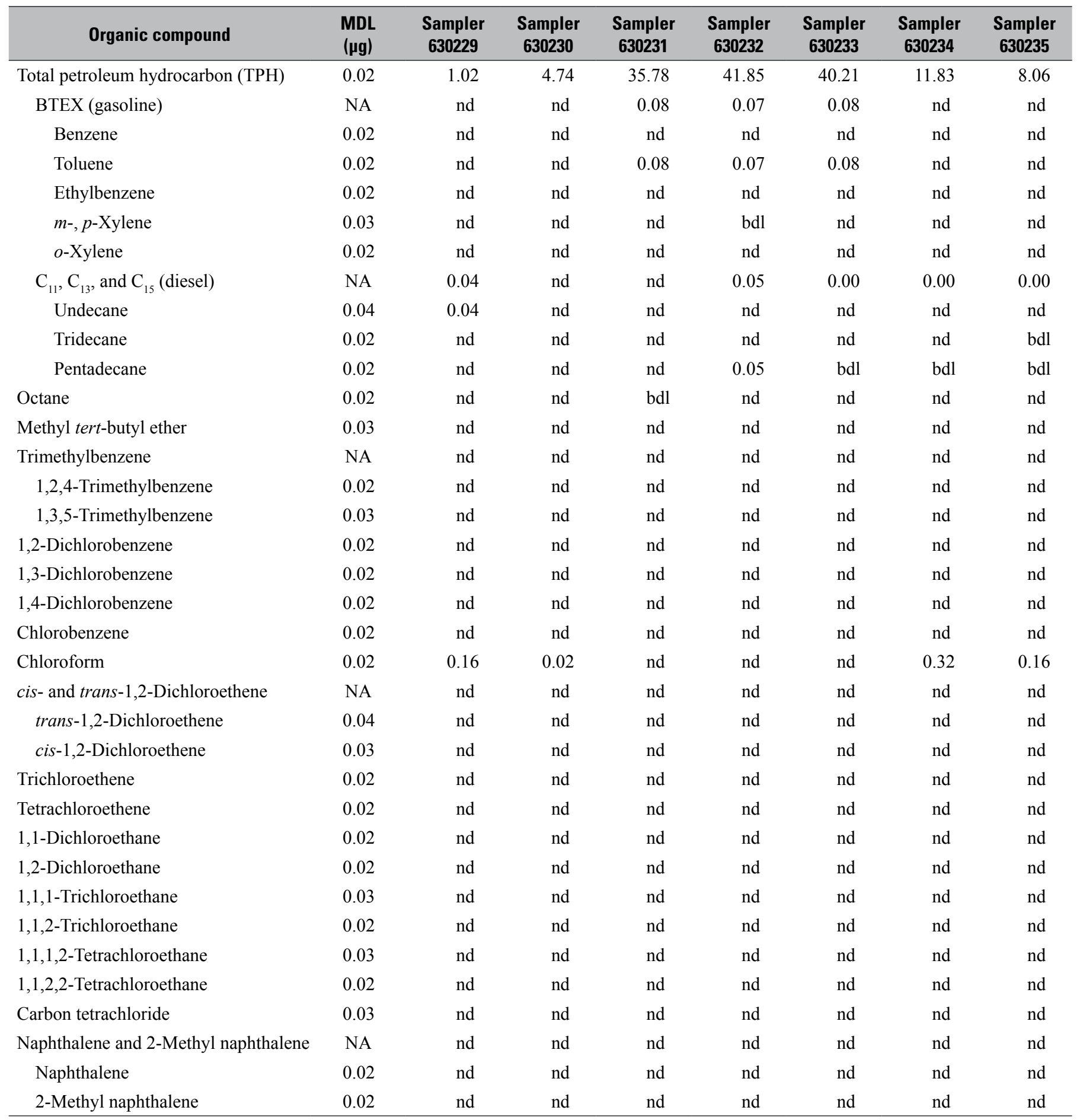


Table 1. Mass of volatile and semivolatile organic compounds detected in soil-gas samplers deployed and collected from the former military police range, Fort Gordon, Georgia, May 20-24, 2010.-Continued

[MDL, method detection level; $\mu \mathrm{g}$, microgram; NA, not applicable; nd, not detected; bdl, below detection level; samplers 630241, 630242, and 630243 are trip blanks]

\begin{tabular}{|c|c|c|c|c|c|c|}
\hline Organic compound & $\begin{array}{l}\text { MDL } \\
(\mu \mathrm{g})\end{array}$ & $\begin{array}{c}\text { Sampler } \\
630236\end{array}$ & $\begin{array}{c}\text { Sampler } \\
630237\end{array}$ & $\begin{array}{c}\text { Sampler } \\
630238\end{array}$ & $\begin{array}{c}\text { Sampler } \\
630239\end{array}$ & $\begin{array}{c}\text { Sampler } \\
630240\end{array}$ \\
\hline Total petroleum hydrocarbon (TPH) & 0.02 & 2.82 & 10.93 & 20.41 & 2.72 & 1.39 \\
\hline BTEX (gasoline) & NA & 0.02 & nd & 0.02 & nd & nd \\
\hline Benzene & 0.02 & nd & nd & nd & nd & nd \\
\hline Toluene & 0.02 & 0.02 & nd & 0.02 & nd & nd \\
\hline Ethylbenzene & 0.02 & nd & nd & nd & nd & nd \\
\hline$m$-, $p$-Xylene & 0.03 & nd & nd & nd & nd & nd \\
\hline$o$-Xylene & 0.02 & nd & nd & nd & nd & nd \\
\hline $\mathrm{C}_{11}, \mathrm{C}_{13}$, and $\mathrm{C}_{15}$ (diesel) & NA & nd & nd & 0.00 & nd & nd \\
\hline Undecane & 0.04 & nd & nd & nd & nd & nd \\
\hline Tridecane & 0.02 & nd & nd & nd & nd & nd \\
\hline Pentadecane & 0.02 & nd & nd & bdl & nd & nd \\
\hline Octane & 0.02 & nd & nd & nd & nd & nd \\
\hline Methyl tert-butyl ether & 0.03 & nd & nd & nd & nd & nd \\
\hline Trimethylbenzene & NA & nd & nd & nd & nd & nd \\
\hline 1,2,4-Trimethylbenzene & 0.02 & nd & nd & nd & nd & nd \\
\hline 1,3,5-Trimethylbenzene & 0.03 & nd & nd & nd & nd & nd \\
\hline 1,2-Dichlorobenzene & 0.02 & nd & nd & nd & nd & nd \\
\hline 1,3-Dichlorobenzene & 0.02 & nd & nd & nd & nd & nd \\
\hline 1,4-Dichlorobenzene & 0.02 & nd & nd & nd & nd & nd \\
\hline Chlorobenzene & 0.02 & nd & nd & nd & nd & nd \\
\hline Chloroform & 0.02 & nd & nd & nd & nd & nd \\
\hline cis- and trans-1,2-Dichloroethene & NA & nd & nd & nd & nd & nd \\
\hline trans-1,2-Dichloroethene & 0.04 & nd & nd & nd & nd & nd \\
\hline cis-1,2-Dichloroethene & 0.03 & nd & nd & nd & nd & nd \\
\hline Trichloroethene & 0.02 & nd & nd & nd & nd & nd \\
\hline Tetrachloroethene & 0.02 & nd & nd & nd & nd & nd \\
\hline 1,1-Dichloroethane & 0.02 & nd & nd & nd & nd & nd \\
\hline 1,2-Dichloroethane & 0.02 & nd & nd & nd & nd & nd \\
\hline 1,1,1-Trichloroethane & 0.03 & nd & nd & nd & nd & nd \\
\hline 1,1,2-Trichloroethane & 0.02 & nd & nd & nd & nd & nd \\
\hline 1,1,1,2-Tetrachloroethane & 0.03 & nd & nd & nd & nd & nd \\
\hline 1,1,2,2-Tetrachloroethane & 0.02 & nd & nd & nd & nd & nd \\
\hline Carbon tetrachloride & 0.03 & nd & nd & nd & nd & nd \\
\hline Naphthalene and 2-Methyl naphthalene & NA & nd & nd & nd & nd & nd \\
\hline Naphthalene & 0.02 & nd & nd & nd & nd & nd \\
\hline 2-Methyl naphthalene & 0.02 & nd & nd & nd & nd & nd \\
\hline
\end{tabular}


Table 1. Mass of volatile and semivolatile organic compounds detected in soil-gas samplers deployed and collected from the former military police range, Fort Gordon, Georgia, May 20-24, 2010.-Continued

[MDL, method detection level; $\mu \mathrm{g}$, microgram; NA, not applicable; nd, not detected; bdl, below detection level; samplers 630241, 630242, and 630243 are trip blanks]

\begin{tabular}{|c|c|c|c|c|c|c|}
\hline Organic compound & $\begin{array}{l}\text { MDL } \\
(\mu g)\end{array}$ & $\begin{array}{c}\text { Sampler } \\
630241\end{array}$ & $\begin{array}{c}\text { Sampler } \\
630242\end{array}$ & $\begin{array}{c}\text { Sampler } \\
630243\end{array}$ & $\begin{array}{l}\text { Method } \\
\text { blank }\end{array}$ & $\begin{array}{c}\text { Method } \\
\text { blank }\end{array}$ \\
\hline Total petroleum hydrocarbon (TPH) & 0.02 & 0.14 & 0.54 & 0.05 & 0.04 & 0.03 \\
\hline BTEX (gasoline) & NA & nd & nd & nd & nd & nd \\
\hline Benzene & 0.02 & nd & nd & nd & nd & nd \\
\hline Toluene & 0.02 & nd & nd & nd & nd & nd \\
\hline Ethylbenzene & 0.02 & nd & nd & nd & nd & nd \\
\hline$m$-, $p$-Xylene & 0.03 & nd & nd & nd & nd & nd \\
\hline$o$-Xylene & 0.02 & nd & nd & nd & nd & nd \\
\hline $\mathrm{C}_{11}, \mathrm{C}_{13}$, and $\mathrm{C}_{15}$ (diesel) & NA & nd & nd & nd & nd & nd \\
\hline Undecane & 0.04 & nd & nd & nd & nd & nd \\
\hline Tridecane & 0.02 & nd & nd & nd & nd & nd \\
\hline Pentadecane & 0.02 & nd & nd & nd & nd & nd \\
\hline Octane & 0.02 & nd & nd & nd & nd & nd \\
\hline Methyl tert-butyl ether & 0.03 & nd & nd & nd & nd & nd \\
\hline Trimethylbenzene & NA & nd & nd & nd & nd & nd \\
\hline 1,2,4-Trimethylbenzene & 0.02 & nd & nd & nd & nd & nd \\
\hline $1,3,5$-Trimethylbenzene & 0.03 & nd & nd & nd & nd & nd \\
\hline 1,2-Dichlorobenzene & 0.02 & nd & nd & nd & nd & nd \\
\hline 1,3-Dichlorobenzene & 0.02 & nd & nd & nd & nd & nd \\
\hline 1,4-Dichlorobenzene & 0.02 & nd & nd & nd & nd & nd \\
\hline Chlorobenzene & 0.02 & nd & nd & nd & nd & nd \\
\hline Chloroform & 0.02 & nd & nd & nd & nd & nd \\
\hline cis- and trans-1,2-Dichloroethene & NA & nd & nd & nd & nd & nd \\
\hline trans-1,2-Dichloroethene & 0.04 & nd & nd & nd & nd & nd \\
\hline cis-1,2-Dichloroethene & 0.03 & nd & nd & nd & nd & nd \\
\hline Trichloroethene & 0.02 & nd & nd & nd & nd & nd \\
\hline Tetrachloroethene & 0.02 & nd & nd & nd & nd & nd \\
\hline 1,1-Dichloroethane & 0.02 & nd & nd & nd & nd & nd \\
\hline 1,2-Dichloroethane & 0.02 & nd & nd & nd & nd & nd \\
\hline 1,1,1-Trichloroethane & 0.03 & nd & nd & nd & nd & nd \\
\hline 1,1,2-Trichloroethane & 0.02 & nd & nd & nd & nd & nd \\
\hline 1,1,1,2-Tetrachloroethane & 0.03 & nd & nd & nd & nd & nd \\
\hline 1,1,2,2-Tetrachloroethane & 0.02 & nd & nd & nd & nd & nd \\
\hline Carbon tetrachloride & 0.03 & nd & nd & nd & nd & nd \\
\hline Naphthalene and 2-Methyl naphthalene & NA & nd & nd & nd & nd & nd \\
\hline Naphthalene & 0.02 & nd & nd & nd & nd & nd \\
\hline 2-Methyl naphthalene & 0.02 & nd & nd & nd & nd & nd \\
\hline
\end{tabular}


Table 2. Mass of volatile and semivolatile organic compounds classified as chemical agents and explosives detected in soil-gas samplers deployed and collected from the former military police range, Fort Gordon, Georgia, September 15-22, 2010.

[MDL, method detection level; $\mu \mathrm{g}$, microgram; nd, not detected; bdl, below detection level; p, para; samplers 644252 through 644256 are trip blanks]

\begin{tabular}{|c|c|c|c|c|c|c|c|}
\hline Compound & $\begin{array}{l}\text { MDL } \\
(\mu g)\end{array}$ & $\begin{array}{c}\text { Sampler } \\
644225\end{array}$ & $\begin{array}{c}\text { Sampler } \\
644227\end{array}$ & $\begin{array}{c}\text { Sampler } \\
644228\end{array}$ & $\begin{array}{c}\text { Sampler } \\
644229\end{array}$ & $\begin{array}{c}\text { Method } \\
\text { blank }\end{array}$ & $\begin{array}{c}\text { Method } \\
\text { blank }\end{array}$ \\
\hline \multicolumn{8}{|c|}{ Chemical agent } \\
\hline Dimethyl disulfide & 0.10 & nd & nd & nd & nd & nd & nd \\
\hline Dimethyl methylphosphonate & 0.10 & nd & nd & nd & nd & nd & nd \\
\hline 1,4-Thioxane & 0.10 & nd & nd & nd & nd & nd & nd \\
\hline Diisopropyl methylphosphonate & 0.10 & nd & nd & nd & nd & nd & nd \\
\hline 1,4-Dithiane & 0.10 & nd & nd & nd & nd & nd & nd \\
\hline Thiodiglycol & 0.20 & nd & nd & nd & nd & nd & nd \\
\hline Benzothiazole & 0.10 & nd & nd & bdl & nd & nd & nd \\
\hline Chloroacetophenones & 0.10 & nd & nd & nd & nd & nd & nd \\
\hline p-Chlorophenyl methyl sulfide & 0.10 & nd & nd & nd & nd & bdl & nd \\
\hline$p$-Chlorophenyl methyl sulfoxide & 0.10 & nd & nd & nd & nd & bdl & nd \\
\hline$p$-Chlorophenyl methyl sulfone & 0.10 & bdl & bdl & bdl & bdl & bdl & bdl \\
\hline \multicolumn{8}{|c|}{ Explosive } \\
\hline Nitrobenzene & 0.10 & nd & nd & nd & nd & nd & nd \\
\hline 1,3-Dinitrobenzene & 0.10 & nd & nd & nd & nd & bdl & nd \\
\hline 1,3,5-Trinitrobenzene & 0.10 & nd & nd & nd & nd & nd & nd \\
\hline 2-Nitrotoluene & 0.10 & nd & nd & nd & nd & nd & nd \\
\hline 3-Nitrotoluene & 0.10 & nd & nd & nd & nd & nd & nd \\
\hline 4-Nitrotoluene & 0.10 & nd & nd & nd & nd & nd & nd \\
\hline 2,4-Dinitrotoluene & 0.10 & nd & nd & nd & nd & bdl & bdl \\
\hline 2,6-Dinitrotoluene & 0.10 & nd & nd & nd & nd & bdl & nd \\
\hline 2,4,6-Trinitrotoluene & 0.10 & nd & nd & nd & nd & nd & nd \\
\hline Compound & $\begin{array}{l}\text { MDL } \\
(\mu g)\end{array}$ & $\begin{array}{l}\text { Method } \\
\text { blank }\end{array}$ & $\begin{array}{c}\text { Sampler } \\
644252\end{array}$ & $\begin{array}{c}\text { Sampler } \\
644253\end{array}$ & $\begin{array}{c}\text { Sampler } \\
644254\end{array}$ & $\begin{array}{c}\text { Sampler } \\
644255\end{array}$ & $\begin{array}{c}\text { Sampler } \\
644256\end{array}$ \\
\hline \multicolumn{8}{|c|}{ Chemical agent } \\
\hline Dimethyl disulfide & 0.10 & nd & nd & nd & nd & nd & nd \\
\hline Dimethyl methylphosphonate & 0.10 & nd & nd & nd & nd & nd & nd \\
\hline 1,4-Thioxane & 0.10 & nd & nd & nd & nd & nd & nd \\
\hline Diisopropyl methylphosphonate & 0.10 & nd & nd & nd & nd & nd & nd \\
\hline 1,4-Dithiane & 0.10 & nd & nd & nd & nd & nd & nd \\
\hline Thiodiglycol & 0.20 & nd & nd & nd & nd & nd & nd \\
\hline Benzothiazole & 0.10 & nd & nd & nd & nd & nd & nd \\
\hline Chloroacetophenones & 0.10 & nd & nd & nd & nd & nd & nd \\
\hline$p$-Chlorophenyl methyl sulfide & 0.10 & nd & nd & nd & nd & nd & nd \\
\hline p-Chlorophenyl methyl sulfoxide & 0.10 & nd & nd & nd & nd & nd & nd \\
\hline$p$-Chlorophenyl methyl sulfone & 0.10 & bdl & bdl & bdl & bdl & bdl & bdl \\
\hline \multicolumn{8}{|c|}{ Explosive } \\
\hline Nitrobenzene & 0.10 & nd & nd & nd & nd & nd & nd \\
\hline 1,3-Dinitrobenzene & 0.10 & nd & nd & nd & nd & nd & nd \\
\hline 1,3,5-Trinitrobenzene & 0.10 & bdl & nd & nd & nd & nd & nd \\
\hline 2-Nitrotoluene & 0.10 & nd & nd & nd & nd & nd & nd \\
\hline 3-Nitrotoluene & 0.10 & nd & nd & nd & nd & nd & nd \\
\hline 4-Nitrotoluene & 0.10 & nd & nd & nd & nd & nd & nd \\
\hline 2,4-Dinitrotoluene & 0.10 & nd & nd & nd & nd & nd & bdl \\
\hline 2,6-Dinitrotoluene & 0.10 & bdl & nd & nd & nd & nd & nd \\
\hline 2,4,6-Trinitrotoluene & 0.10 & nd & nd & nd & nd & nd & nd \\
\hline
\end{tabular}


Table 3. Inorganic constituents detected in soil samples collected at the former military police range from land surface to 6 inches, samples 1 through 5, Fort Gordon, Georgia, August 30, 2010.

[USEPA RSL, U.S. Environmental Protection Agency regional screening level, Industrial Soil; SC DHEC, South Carolina Department of Health and Environmental Control; $\mu \mathrm{g} / \mathrm{g}$, microgram per gram; mg/kg, milligram per kilogram; for soil, $1 \mu \mathrm{g} / \mathrm{g}$ is equivalent to $1 \mathrm{mg} / \mathrm{kg}$, and $1 \mathrm{mg} / \mathrm{kg}$ is equivalent to 1 part per million (ppm); *, Resource Conservation and Recovery Act (RCRA) metal; - , no data; <, less than; yellow highlight indicates value is higher than SC DHEC background; Note: selenium and mercury were not analyzed]

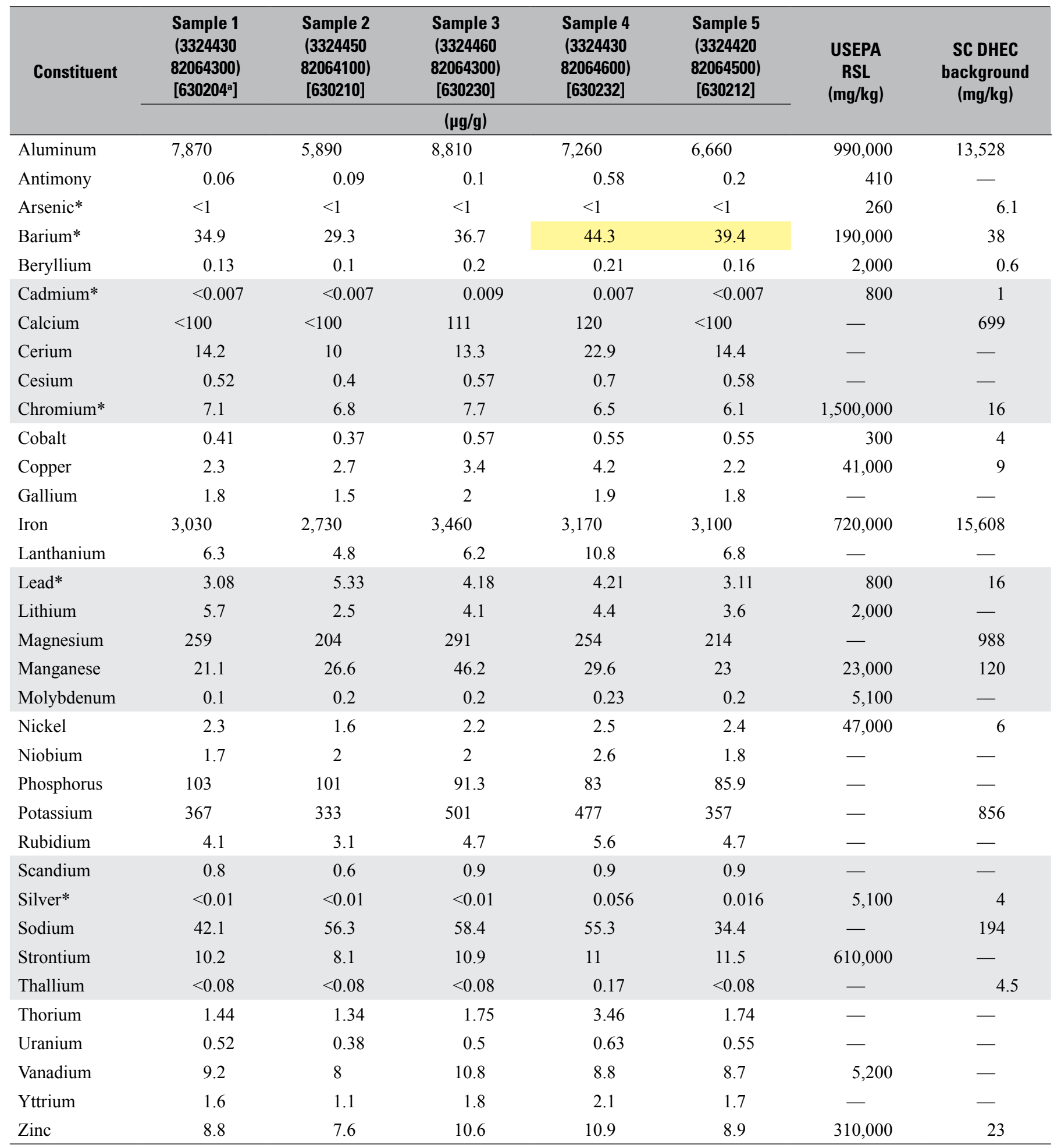

${ }^{\text {a }}$ Closest May soil-gas sampler. 
Manuscript approved for publication, April 1, 2011

Edited by Kay E. Hedrick

Layout by Caryl J. Wipperfurth

For more information concerning the research in this report, contact USGS South Carolina Water Science Center

720 Gracern Road, Suite 129

Columbia, SC 29210

telephone: 803-750-6100

http://sc.water.usgs.gov 
